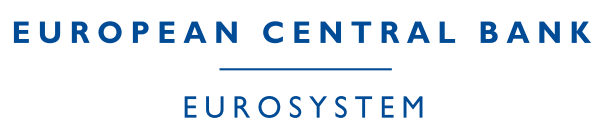

WORIING PAPER SERIES

NO I49I / NOVEMBER 20 I 2

\title{
TRADE OPENNESS REDUCES GROWTH VOLATILITY WHEN COUNTRIES ARE WELL DIVERSIFIED
}

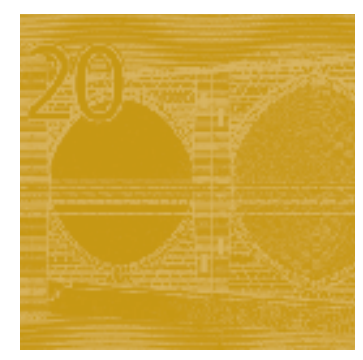

Mona Haddad, Jamus Jerome Lim, Cosimo Pancaro and Christian Saborowski

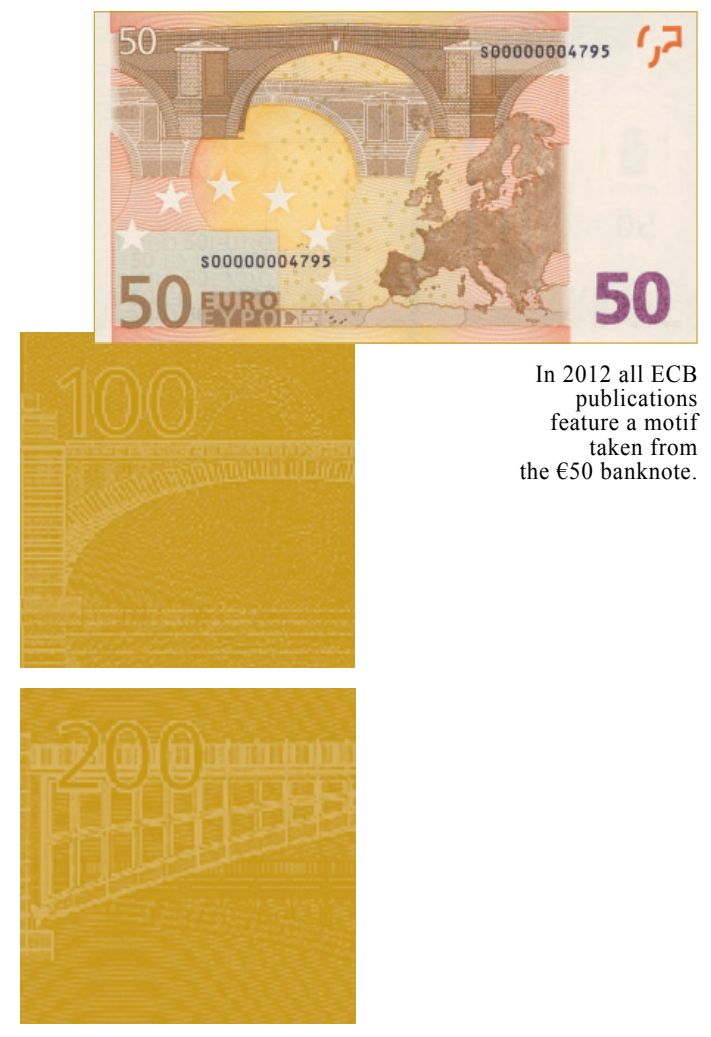

NOTE: This Working Paper should not be reported as representing the views of the European Central Bank (ECB). The views expressed are those of the authors and do not necessarily reflect those of the ECB. 


\section{Acknowledgements}

We thank Jean Francois Arvis, Robert Blotevogel, Paul Brenton, Olivier Cadot, Phil Levy, Norman Loayza, Ben Shepherd, an anonymous referee, and participants at the 2010 World Bank Economists' Forum for helpful conversations and comments on this work, as well as Norman for generously sharing his data; we, however, are solely responsible for any errors that remain. The findings, views and interpretations expressed herein are those of the authors and should not be attributed to the ECB, IMF, or World Bank, their Executive Boards, or their management.

\section{Mona Haddad}

at The World Bank; e-mail: mhaddad@worldbank.org

\section{Jamus Jerome Lim (corresponding author)}

at The World Bank; e-mail: jlim@worldbank.org

\section{Cosimo Pancaro}

at European Central Bank; e-mail: cosimo.pancaro@ecb.europa.eu

\section{Christian Saborowski}

at International Monetary Fund; e-mail: CSaborowski@imf.org

(C) European Central Bank, 2012

\section{Address}

Kaiserstrasse 29, 60311 Frankfurt am Main, Germany

Postal address

Postfach 1603 19, 60066 Frankfurt am Main, Germany

\section{Telephone}

+496913440

\section{Internet}

http://www.ecb.europa.eu

\section{Fax}

+496913446000

All rights reserved.

ISSN 1725-2806 (online)

Any reproduction, publication and reprint in the form of a different publication, whether printed or produced electronically, in whole or in part, is permitted only with the explicit written authorisation of the ECB or the authors.

This paper can be downloaded without charge from http://www.ecb.europa.eu or from the Social Science Research Network electronic library at http://ssrn.com/abstract_id=1565983. 


\begin{abstract}
This paper addresses the mechanisms by which trade openness affects growth volatility. Using a diverse set of export concentration measures, we present strong evidence pointing to an important role for export diversification in conditioning the effect of trade openness on growth volatility. Indeed, the effect of openness on volatility is shown to be negative for a significant proportion of countries with relatively diversified export baskets.
\end{abstract}

KEYWORDS: Export diversification, growth volatility, trade openness JEL Classification: F15, F43, O24 


\section{Non-Technical Summary}

While it is widely believed that trade openness is, under suitable conditions, positively

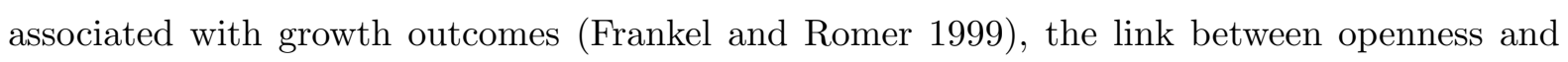
growth volatility is less well understood. As trade integration deepens, economies are naturally more exposed to external shocks. However, does this automatically imply that more open economies must experience greater growth volatility, or are there factors that may condition whether the larger exposure translates into a more volatile growth path? Despite an extensive existing literature on the subject, there is no clear consensus to date.

This paper seeks to contribute to this line of research and thus proceeds by asking two questions: first, does the effect of trade openness on growth volatility vary with the degree of concentration of a country's export basket? Second, if such conditioning exists, is there a level - in terms of a given export concentration measure - where, for the average country, the total effect of trade openness on growth volatility changes from negative to positive?

Our empirical strategy begins with the computation of a variety of export concentration indicators, which we use as measures of the extent of export concentration in any given country, across both products and markets. We then utilize these measures to explore the relationship between concentration, trade openness, and volatility, while controlling for important additional sources of income volatility. We also obtain standard errors for the joint effect of the openness indicator and its interaction with concentration, and establish confidence-bound threshold values whereby the total effect of the openness variable on growth volatility switches sign. One major empirical concern is the possible endogeneity in the link between growth volatility and trade openness. While we have postulated a direct effect stemming from openness to volatility, we are aware that the converse is also possible, namely that trade policy responds to an increase in growth volatility. Our preferred choice of estimator to deal with the likely (weak) endogeneity in the relationship is the system GMM procedure proposed by (Arellano and Bover $19 \overline{9} 5$ and Bonditions reverse causality in the openness variable via the explicit incorporation of predicted trade flows (Frankè and Romer. $1 \overline{9} 9 \overline{9}$ ) as an exogenous instrument.

With regard to the first question of interest - whether the effect of openness is moderated by the extent of diversification - we find strong evidence pointing to the important role export diversification plays in reducing the vulnerability of countries to global shocks; while we were agnostic about the relative importance of product versus market diversification ex ante, we also find that product diversification clearly moderates the effect of trade openness on growth volatility, while the market concentration measures yield much more mixed results. With regard to our second research question, we find that about half of the countries in our sample are sufficiently diversified to benefit from more openness in terms of lower output volatility. 


\section{Introduction}

While it is widely believed that trade openness is, under suitable conditions, positively associated with growth outcomes ("Frankel and Romer"1999), the link between openness and growth volatility is less well understood. As trade integration deepens, economies are naturally more exposed to external shocks. However, does this automatically imply that more open economies must experience greater growth volatility, or are there factors that may condition whether the larger exposure translates into a more volatile growth path?

Despite an extensive existing literature on the subject, there is no clear consensus to date whether greater openness comes at the cost of a more volatile growth path. This paper seeks to contribute to this line of research and, while agnostic as regards the sign of the average effect of trade openness on volatility, argues that the vulnerability of countries to idiosyncratic external shocks should be reduced when these countries are better diversified in their exports in Our hypothesis provides significant nuance to much of the existing understanding in academic research, and to the policy advice that hews to greater or lesser trade liberalization without regard for a given economy's existing export structure.

The intuition underlying the controversy surrounding the relationship between openness and volatility is simple: in general, an open economy is expected to face higher exposure to external shocks than one that is less reliant on trade to spark economic activity. However, since access to external markets also shields an economy against significant growth slowdowns due to domestic demand shortages, it is not ex-ante clear whether greater openness should be associated with higher or lower growth volatility.

The argument we make in this paper is that, irrespective of whether the effect of trade openness on output volatility is positive or negative on average, openness lowers output volatility in sufficiently diversified economies, while it increases volatility in those with more concentrated export baskets. This assertion is based on a twofold argument. First, idiosyncratic shocks to specific product markets are more likely to lead to large swings in a country's export volumes and terms of trade (ToT) if its exports are concentrated on few sectors; similarly, idiosyncratic shocks to demand in specific export destinations are likely to lead to larger swings in economies that export to a small number of geographic regions or countries. Second, a higher degree of diversification would likely imply that a country is more involved in both implicit and explicit international insurance schemes. These could take the form of involvement in international production chains, joint ventures, international lending or formal insurance contracts and would serve not only to cushion the impact of external shocks but also those of domestic origin. It is in this sense that the effect of openness on volatility may not only be lower in diversified economies but may actually be negative.

Our analysis thus proceeds by asking two questions: first, does the effect of trade openness

\footnotetext{
${ }^{1}$ Although the degree of import diversification may just as well affect growth volatility for much the same reasons, this study focuses solely on export diversification, since the latter explicitly articulated as a policy goal, while the former is often dependent on broader questions of import elasticities and market access.
} 
on growth volatility vary with the degree of concentration of a country's export basket? Second, if such conditioning exists, is there a level - in terms of a given export concentration measurewhere, for the average country, the total effect of trade openness on growth volatility changes from negative to positive?

To our knowledge, these questions have not been adequately addressed in the existing empirical literature. Several empirical papers have considered whether trade openness, per se, increases macroeconomic volatility (Rodrik" $\overline{9} \overline{9} \overline{7})$, but these have not taken the additional step of asking whether the effects of openness are unambiguous in their impact. (Raddatzi, 2007) applies a VAR methodology to show that external shocks, such as those transmitted to prices, foreign growth, and real interest rates, have a positive significant impact on the volatility of real activity in low-income economies. Yet, while external shocks are crucial in accounting for external sources of variation, such shocks can only explain a small fraction of the long run

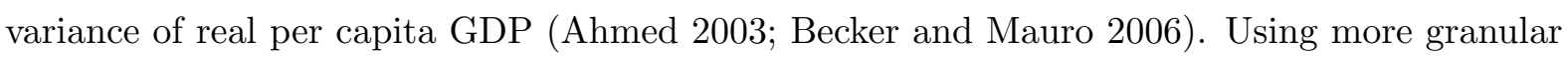
industry level data, idi Giovanni and Levchenko $(2009)$ investigate the channels through which trade openness might affect volatility. They document that sectors more open to international trade are more volatile, but they do not consider the interaction between openness and special-

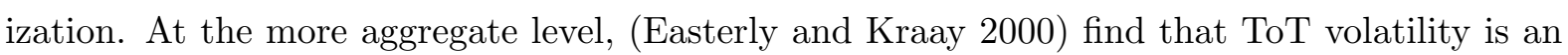
important driver of growth volatility, especially for smaller states. Yet, they argue that ToT volatility typically experienced by small economies is due mainly to their openness, and that export concentration plays only a minor role.

Possibly the closest studies in spirit to ours are three papers by

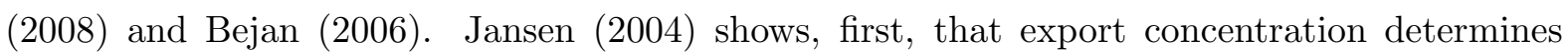
ToT volatility, and second, that ToT volatility drives income volatility. However, the analysis is focused only on a cross-section of economies, and no explicit link is made between the two findings. ${ }_{1}^{1}$ Cavallo $(\overline{2} \overline{0} \overline{0} \overline{8})$ does consider terms of trade volatility as a conditioning factor on the relationship between openness and volatility, while export concentration is only introduced as an additional control variable. The paper finds that openness has an overall stabilizing effect on volatility, while the degree of export concentration is not a significant explanatory factor. 'Bejani $(\overline{2} \overline{0} \overline{0})$ analyses the relationship between trade openness and output volatility and finds that higher trade openness is associated with higher output volatility. However, when proxies for government size and external risks, such as export concentration and terms of trade volatility, are included in the analysis, higher trade openness ceases to be associated with higher output

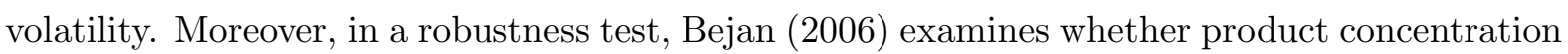
of exports conditions the relationship between openness and volatility. She finds that the coefficient of the interaction term is positive and significant only when advanced countries are considered. However, while this paper hints at the mechanism discussed in the present paper, it does not systematically study this relationship, nor does it assess explicitly whether the effect of openness on volatility can turn negative for the most diversified economies.

Our contribution differs from the existing literature in several ways. First, we systemati- 
cally explore the conditioning effect of export concentration on the relationship between trade openness and volatility. Second, we obtain turning points in terms of level of concentration at which the total effect of openness on growth volatility changes sign. Finally, our study considers a broader conception of diversification, in terms of both market and product concentration.

Our empirical strategy begins with the computation of a variety of export concentration indicators, which we use as measures of the extent of export concentration in any given country, across both products and markets. We then utilize these measures to explore the relationship between concentration, trade openness, and volatility, while controlling for important additional sources of income volatility that stem from domestic and external sources. We also obtain standard errors for the joint effect of the openness indicator and its interaction with concentration, and establish confidence-bound threshold values whereby the total effect of the openness variable on growth volatility switches sign. One major empirical concern is the possible endogeneity in the link between growth volatility and trade openness. While we have postulated a direct effect stemming from openness to volatility, we are aware that the converse is also possible, namely that trade policy responds to an increase in growth volatility. Our preferred choice of estimator to deal with the likely (weak) endogeneity in the relationship is the system GMM

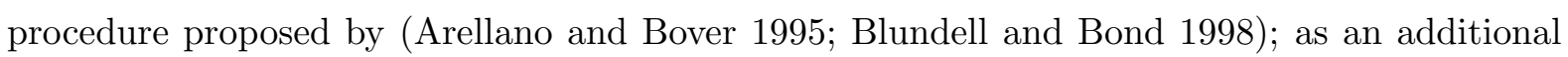
robustness check, however, we also explicitly control for reverse causality in the openness variable via the explicit incorporation of predicted trade flows (Frankel and Romeri $\overline{9} 9 \overline{9})$ as an exogenous instrument.

Our results are generally supportive of our priors. With regard to the first question of interest - whether the effect of openness is moderated by the extent of diversification - we find strong evidence pointing to the important role export diversification plays in reducing the vulnerability of countries to global shocks; while we were agnostic about the relative importance of product versus market diversification ex ante, we also find that product diversification clearly moderates the effect of trade openness on growth volatility, while the market concentration measures yield much more mixed results. With regard to our second research question, we find that about half of the countries in our sample are sufficiently diversified to benefit from more openness in terms of lower output volatility.

We conduct a battery of robustness checks to test whether our results are sensitive to changes in the sample or model specification, and we verify that our findings are indeed relatively robust. One interesting result arising from our robustness checks is the fact that the main findings do not change markedly when high-income economies are excluded from the analysis, even though the sample size falls substantially. In contrast, the relationship does not always hold when we exclude low-income economies from the analysis. This suggests that low- and middle-income economies are indeed the main drivers of the key result in this paper. This is intuitive given that developing countries are likely to have only limited access to other forms of insurance against external shocks.

The rest of this paper is organized as follows. In Section $22_{-1}^{1}$ we describe the dataset we 
use and present some descriptive information for the key variables of interest; this section also outlines the econometric approach that we adopt. Section 3 in reports our main results, discusses our main findings, and briefly describes the host of robustness tests that we implemented. A final section concludes.

\section{Data and Methodology}

\subsection{Description of Data}

Our dataset comprises an unbalanced panel of 77 developing and developed economies over the period 1976-2005 (Appendix Table î. in Appendix Table of volatility measures) for all variables in the model

We do so for two main reasons. First, the measures of export diversification that we employ are potentially subject to noise that is not necessarily reflective of a true diversification trend in the export basket. Other control variables such as the per capita growth rate may be subject to business cycle variations. Five-year averaging serves as a filter that would remove noise and mute cyclical elements in the data. Second, the econometric model we employ as our benchmark (system GMM) was designed to work with data that include a large cross sectional and a short time series dimension. Taking 5-year averages yields a maximum of 6 time periods for any given country, which would then satisfy this short time-series requirement.

Our main dependent variable is output growth volatility, measured as the standard deviation of GDP per capita growth within each 5-year period. While it is entirely plausible to substitute output for growth volatility, we refrain from doing so for three main reasons. First, even a stable growth path at a constant annual rate of growth will generate a positive volatility measure, even though this is both a desirable and perfectly forecastable outcome. Second, policymakers are generally more concerned with maintaining a stable growth rate, as opposed to stable output levels, since it is the former that directly affects the planning horizon. Third, we follow the standard approach in the literature on the effects of volatility, and these papers (Easterly and Kraay,'2000; 'Ramey and Ramey volatility.

The two main independent variables of interest are export concentration and trade openness. Because we do not hold any ex ante preferences toward either product or market export concentration, we include a variety of export concentration measures that capture both dimensions in any given country. These are fairly standard, and include the top five and top ten shares of

\footnotetext{
${ }^{2}$ It can be argued that using non-normalized standard deviations as measures of volatility risks overstating volatility for countries with high growth rates relative to those with low growth rates. We refrain from normalizing standard deviations for several reasons. First, the issue is likely to be less of a problem in a dynamic panel setting such as in this paper. Second, in practice the differences in standard deviations of growth typically turn out not to be driven by differences in mean levels of growth. Third, normalizing by the average may lead to large outliers when the average growth rate is close to zero.
} 
products and markets (5/10 product and 5/10 market) as well as Herfindahl-Hirschman indexes for products (product Herfindahl) and markets (market Herfindahl).

Consistent with much of the literature, we compute trade openness as the ratio of the sum of exports and imports to GDP, while financial openness is measured with an index of restrictions

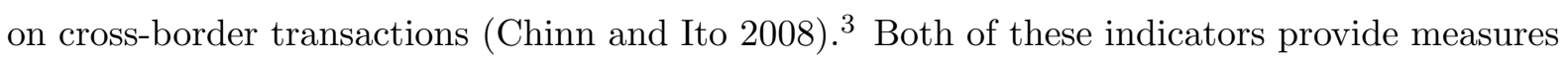
of the actual exposure of a country to international markets. This implies that they reflect both structural and policy-related characteristics of a country. Appendix Table summary statistics for the key explanatory and control variables. The appendix also reports additional descriptive statistics of interest, including cross correlations between the different export concentration measures (Appendix Table the main explanatory variables of interest (Appendix Table

Unsurprisingly, the three product concentration measures and the three market concentration measures are highly correlated within each of the two groups, whereas the correlation across groups is low and mostly below $50 \%$. This correlation structure for concentration is well known, and serves as a motivation for our interest in deploying both market and product indicators to uncover whether it is both diversification across products and markets, or just one of the two, that matter in reducing the vulnerability of economies to external shocks.

While we defer a rigorous analysis of our key questions to the next section, it is helpful at this point to consider the plausibility of the hypotheses by examining the link between volatility and openness descriptively, contingent at different parts of the distribution of the concentration measure. We do so by plotting growth volatility against trade openness separately for observations belonging to the lower and upper quartiles (as well as the two middle quartiles jointly) of two selected concentration measures, namely the 5-product and 5-market indicators. The plots are shown in Figure iín:

Although awaiting formal econometric verification, the plots do confirm our hypothesis in the case of the product concentration indicator: the effect of openness on growth volatility is negative when exports are well diversified across products, close to zero when product concentration is at an average level, and positive when concentration is in the upper quartile of the distribution. This finding is reasonably robust to alternative measures of product concentration (not reported). The same cannot be said for the market indicator. Although the evidence is at this point only suggestive, it indicates that product diversification may be more important than market diversification in shielding an economy from the adverse impacts of external shocks.

\footnotetext{
${ }^{3}$ In addition to these measures, we have explored alternative measures of trade and financial openness, such as the import share of GDP and the ratio of FDI and portfolio liabilities to GDP, respectively. Our central results were not altered, although some of the control variables fell out of statistical significance (while maintaining their directionality). These regressions are available upon request.
} 


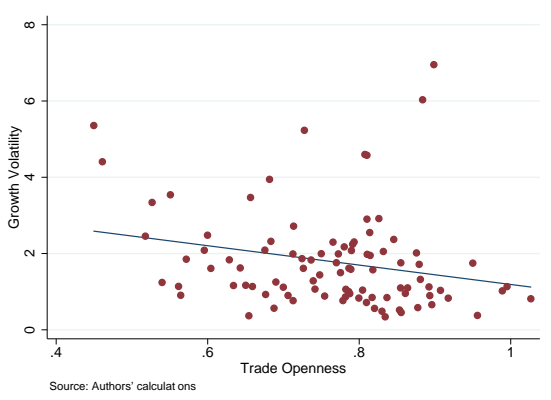

(a) 5-product is low

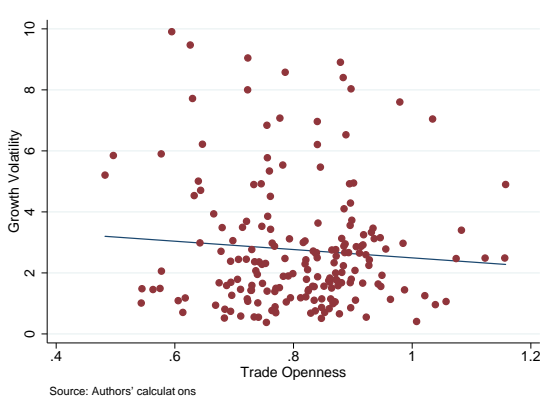

(c) 5-product is medium

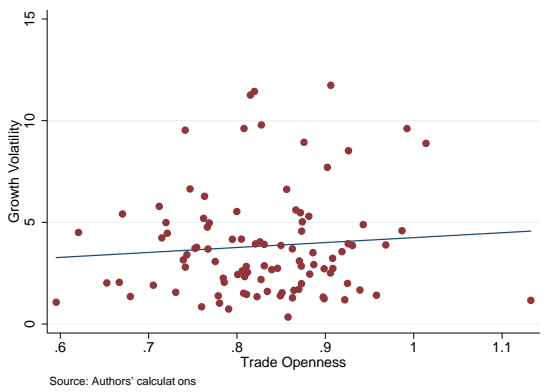

(e) 5-product is high

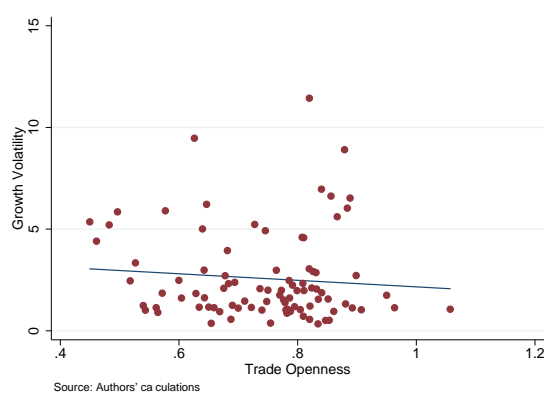

(b) 5-market is low

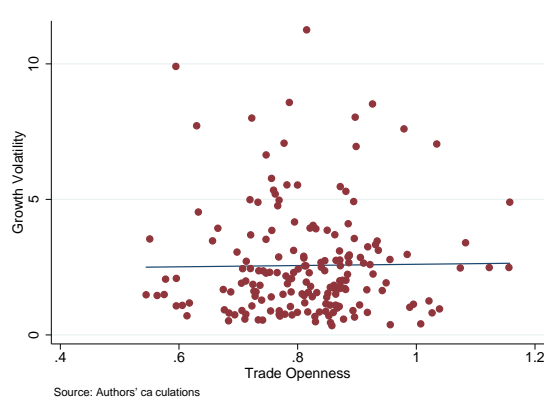

(d) 5-market is medium

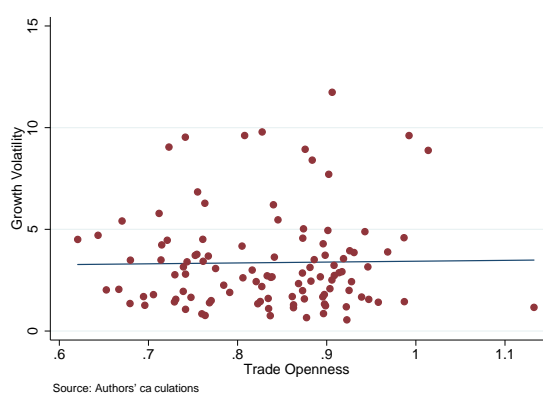

(f) 5-market is high

Figure 1: Plots of standard deviation of GDP per capita growth against trade openness, with each row of the left (right) column capturing country-year observations from low, medium, and high levels of product (market) concentration, with fitted (navy) regression lines.

\subsection{Empirical Model and Estimation Strategy}

The benchmark linear dynamic panel data model we estimate in this study is given by

$$
\begin{aligned}
\operatorname{GDPVOL}_{i, t}= & \alpha_{i}+\beta_{1} O P E N_{i, t}+\beta_{2} \operatorname{CON}_{i, t}+\beta_{3} O P E N_{i, t} \times C O N_{i, t} \\
& +\gamma \mathbf{X}_{i, t}+\epsilon_{i, t},
\end{aligned}
$$

where the dependent variable, GDPVOL $L_{i, t}$, is the standard deviation of real GDP per capita growth for country $i$ for period $t, O P E N_{i, t}$ is trade openness (measured as total trade as a 
share of GDP), $C O N_{i, t}$ is a given measure of export concentration, $O P E N_{i, t} \times C O N_{i, t}$ is the interaction of the two previous variables, and $\mathbf{X}_{i, t}$ is a $(1 \times m)$ vector of control variables; $\alpha_{i}$ and $\epsilon_{i, t} \sim N\left(0, \sigma_{\epsilon}^{2}\right)$ are the individual-specific effects and i.i.d. disturbance terms, respectively.

Our theoretical priors suggest that the effect of trade openness on growth volatility is positive in the upper part of the distribution of export concentration, but that this effect decreases and eventually becomes negative as countries become more diversified. $\beta_{3}>0$ is the necessary condition to validate this hypothesis. We are ex-ante agnostic with regard to the sign of $\beta_{1}$.

In addition, (11) also allows for the determination of a point in the distribution of a given concentration measure at which the impact of openness on growth volatility changes sign. Identifying these turning points allows us to determine the share of countries in our sample that would be expected to benefit from a marginal increase in trade openness via a reduction in growth volatility. While our model is certainly not comprehensive enough to make specific predictions for individual countries, it does allow us to understand how frequent a negative relationship between openness and volatility is likely to be in our large sample of countries. Determining the turning point requires setting the total effect of openness on growth volatility to zero, followed by solving for the level of the concentration measure that is implied by the resulting equation. We then determine joint standard errors between the openness variable and the interaction term, in order to be able to draw confidence bands around the point estimate.

We include a range of confounding variables in the vector $\mathbf{X}$ as controls that have been shown to be among the main sources of growth volatility in the literature (Loayza, Rancière, iServén and Venturai 2007 i). In our preferred specification, these include inflation volatility, exchange rate volatility, an indicator for the frequency of systemic banking crises, as well as the volatility of foreign shocks, such as foreign growth volatility, the volatility of capital flows to the region and ToT volatility. Many of these are second-moment analogs to major structural variables that are found to be associated with growth. Volatility in the terms of trade and capital flows capture the effect of shocks related to cross-border flows, while volatility in the exchange rate and inflation may be a source of macroeconomic instability and consequently of growth volatility. Foreign growth volatility serves as a proxy for the effect of negative spillovers resulting from contractions in the economies of main trading partners, while the dummy for banking crises allows for the possibility of discontinuities in growth volatility that results in the event of a banking crisis.

As discussed in the introduction, endogeneity is generally of concern in regressions of growth on trade openness, as there is little doubt that current and past realizations of growth can be important factors in driving both exports and imports - and hence trade openness - through their influence on policy choices. It is straightforward to think of political economy arguments that may explain why a higher level of growth volatility can lead to a less open economy. For example, this may occur if policymakers choose policies affecting trade openness as a response to large fluctuations in GDP because they regard openness as a potential source of this volatility.

A consistent estimator that does allow for the joint (weak) endogeneity of all explanatory 
variables including the lagged dependent variable is the GMM difference estimator derived by ${ }_{1}^{A}$ Arellano and Bond (1991). However, this estimator requires the model to be differenced and is subject to instrument weakness which can influence the asymptotic and small sample performance of the estimator. Based on the work of Arellano and Boveri (1995), 'Blundell and Bond (1998) develop a system GMM estimator that combines the regression in differences with the regression in levels to attenuate these weaknesses although they remain a concern! More generally, it is possible to imagine real world scenarios under which future shocks to growth volatility may drive today's policy decisions towards changes in trade openness. There is then a risk of misspecification given that the system estimator only allows for the presence of weak endogeneity. However, we expect this risk to be relatively limited and, in the absence of a better alternative, regard our baseline specification as the appropriate choice for our analysis.

\section{Estimation Results and Discussion}

\subsection{Main Results}

In this section, we estimate the empirical model defined in (1,1ij) for different choices of the concentration indicator $C O N_{i, t}$. Although our preferred estimator is the system GMM estimator, we complement it with random effects estimates, which serve as an important baseline for the purposes of comparison. Estimates for (1) Appendix Table

We begin the analysis attempting to understand how trade openness affects growth volatility on average, in other words, independently of the concentration indicators. For this purpose, specification $G 1$ in Table $1 \overline{1}=1$ and $R 1$ in Appendix Table the concentration indicator $C O N_{i, t}$ and the interaction term $O P E N_{i, t} \times C O N_{i, t}$. Here, the coefficient on $O P E N_{i, t}$ represents the average effect of trade openness on growth volatility across the entire sample, and independently of variables such as export concentration indicators that might condition the effect in reality.

The tables show that the coefficient is positive and significant at the 10 percent level in the random effects regression, and negative and insignificant in our preferred model, the system GMM regression. The evidence with regard to the effect of trade openness on growth volatility is thus inconclusive. It appears that an increase in trade openness has little or no effect on growth volatility on balance as the channels through which trade openness may impact growth

\footnotetext{
${ }_{1}^{4}$ Bun and Windmeijer estimator as well. See also "Channing, Jones and Tarp of moment conditions.

${ }^{5}$ Fixed effects estimates are available on request. The results are qualitatively and quantitatively very similar to those obtained using the random effects estimator, although some of the variables of interest become insignificant. We choose to report the random rather than the fixed effects estimates for two reasons. First, the Hausman test favors the random over the fixed effects estimator, and hence the random effects coefficients are more efficient. Second, the fact that the fixed effects estimator disregards between-group variation may be particularly problematic in our study. The reason is that between-group variation in the diversification measures may be more reliable as an actual measure of relative differences in export concentration, rather than within-group variation.
} 
volatility according to theory balance out.

To clarify how export concentration comes into play, we proceed with estimates of the fullyspecified model in (1) By and large, across all regressions in Tables $1 \overline{1} 1$ and variables enter with the expected signs when significant. For example, volatility in the ToT is mostly positively related to growth volatility and significant, a finding that echoes others in the literature (Easterly and Kraay" 2000 crisis throughout most of the regressions is associated with increased growth volatility (which, although seemingly tautological, emphasizes the fact that the preponderance of financial crises spill over to the real economy).

Moreover, both increased inflation volatility and increased volatility in capital flows to the region have a positive and mostly significant impact on growth volatility. Given the recent controversy over the benefits of financial globalization, the coefficient on financial openness is an interesting one. It enters with a negative sign in most of our regressions and is almost always statistically significant at the 5 percent level. This finding may be rationalized as follows: financial openness allows countries to accede a wider array of financial assets and thus to diversify their risk. Therefore, deeper financial integration implies higher risk sharing and a reduction in growth volatility. Our results are consistent with $(\overline{2} \overline{0} \overline{6})$ who consider several measures of equity and capital account liberalization in a large country sample and find evidence in favor of a negative relationship between financial openness and growth volatility. 'Calderón et al. (2005) similarly find results that are in line with ours.

We now move on to considering the interaction between openness and export concentration in our regressions, which addresses our primary questions of interest. Since the measure of concentration is central to our analysis of this question, we report results for the benchmark specification of (1, i d using a range of alternative product and market concentration measures to represent $C O N_{i, t}$. In the case of product concentration, these correspond to the: (a) Product Herfindahl; (b) 5 product; and (c) 10 product, and are reported in columns G2-G4 (Table and R2-R4 (Appendix Table ${ }^{A} \cdot \bar{b}$ ). Regressions using the analogous market indicators are presented in columns G5-G8 (Table $1 \overline{1} 1$ i) and $R 5-R 8$ (Appendix Table

We begin by discussing the random effects estimates, and focus initially on the regressions

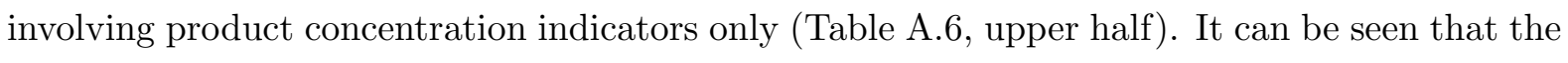
coefficient on the concentration variable is negative throughout the specifications we run; it is, aside from one exception, always significant at the 90 percent level or higher. It is important to keep in mind, however, that the total effect of concentration on growth volatility is conditional on the level of openness, much like the effect of openness on growth volatility, which is conditional on the level of concentration. As we are mainly interested in the latter, it suffices to say that, as expected, the total effect of concentration on volatility is positive for all but the least open economies!

\footnotetext{
6 Kose, Prasad, Rogoff and Wei (2009) provide an extensive review of the vast theoretical and empirical literature that studies the relationship between financial openness and growth volatility.

${ }^{7}$ The total effect of export concentration on volatility can be calculated as $\beta_{2}+\beta_{3} O P E N_{i, t}$. It is intuitive that
} 
The trade openness indicator is mostly insignificant in our regressions but carries a negative coefficient. The coefficient estimates for the interaction terms are positive and, in the case of product concentration, always significant. This finding would suggests that the effect of trade openness on growth volatility is indeed conditioned by the degree of export diversification, confirming our initial hypothesis. However, as discussed earlier, endogeneity is a potential concern for our estimates. We therefore treat the system GMM results in Table [1] as our benchmark since, in spite of the concerns discussed previously, this estimator allows accounting explicitly for possible (weak) endogeneity.

Table 1: Benchmark system GMM regressions for growth volatility on openness, concentration, and controls ${ }^{\dagger}$

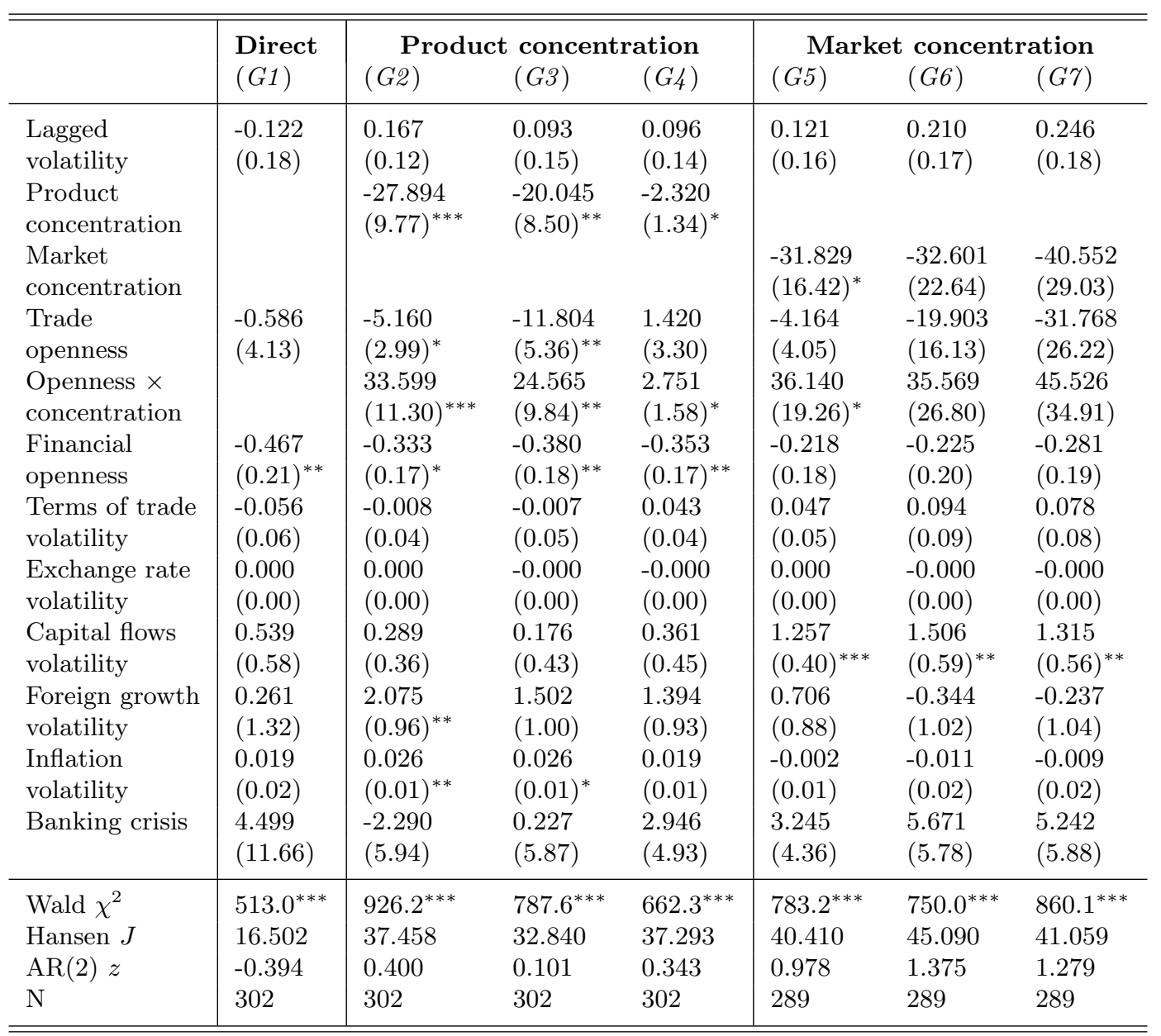

${ }^{\dagger}$ Notes: Heteroskedasticity and autocorrelation-robust (asymptotic) "Windmeijer" (2005)-corrected standard errors reported in parentheses. ${ }^{*}$ indicates significance at 10 percent level, ${ }^{* *}$ indicates significance at the 5 percent level, and ${ }^{* * *}$ indicates significance at the 1 percent level. Period dummies and a constant were included, but not reported.

The results are qualitatively very similar to those reported in Appendix Table

relatively closed economies benefit less from diversification as an implicit insurance against idiosyncratic external shocks. However, one would have expected the effect to be positive throughout insofar as export differentiation is closely correlated with production differentiation. 
trade openness variable enters consistently with a negative sign. The interaction term is always positive and significant at the 10 percent level. Using this preferred model specification, we thus again find supportive evidence for our claim that the effect of trade openness on growth volatility falls, the more diversified a country is in its exports. Throughout all the specifications, the Hansen $J$ test of overidentifying restrictions confirms that the (internal) instruments are valid, and the Arellano-Bond test rejects significant second-order serial correlation in the error term. Finally, while several control variables fall out of statistical significance, the volatility of foreign growth and capital flows remain influential.

We move on to consider the estimates for the regressions involving indicators of market instead of product concentration in Table 1َ1 and Appendix Table any ex ante hypothesis as to whether product or market diversification should matter more in better shielding an economy from shocks. However, while Tables claim regarding the moderating effect of product diversification, the same cannot be said of market diversification. Only in two regressions (specifications G5 and R5) is the interaction term significant at the 10 percent level. This suggests that evidence in favor of a role for market alongside product diversification in shielding an economy from shocks is limited at best. Furthermore, Wald tests (not reported) suggest that the openness variable and the interaction term are jointly insignificant in all of the regressions involving indicators of market concentration, implying that turning points in the distributions of the market concentration indicators - at which the total effect of openness on growth volatility changes sign — cannot be established with confidence. In contrast, as shown in the subsequent section, joint significance can indeed be confirmed in the case of the regressions involving product concentration indicators.

In sum, we find strong evidence for an important role of export diversification in reducing the vulnerability of countries to global shocks, allowing us to answer the first part of our research question - whether the effect of trade openness on growth volatility varies with the level of export diversification - with a clear affirmation. It does appear, however, that the role of product diversification is more important in this context than that of market diversification.

\subsection{Turning Points for the Effect of Openness on Volatility}

Drawing further conclusions from our estimates requires us to establish turning points in the respective concentration indicators at which the effect of openness on growth volatility switches sign. In light of the findings of the previous section, namely that the interaction term is mostly insignificant for market concentration indicators (and that the openness variable and the interaction term are always jointly insignificant), we are limited to the regressions involving product concentration indicators for this exercise. Turning points are then established on the basis of the system GMM estimates (specifications G2-G4), which represent our preferred model.

The total effect of openness on volatility is the sum of the coefficients on the openness variable and the product of the interaction term and the coefficient on the interaction term. It 
is straightforward to determine turning point values at which the total effect of openness on growth volatility changes sign. In other words, we can identify a value for each concentration measure which, in theory, a country needs to underscore (in practice, we do not suggest that our model is comprehensive enough to make country specific predictions) in order to benefit from a marginal increase in trade openness in terms of a reduction in growth volatility. The turning point can be identified by setting the total effect of trade openness on growth volatility to zero, that is, by taking $\beta_{1} O P E N+\beta_{3} O P E N \times C O N^{*}=0$, and solving for the value of the critical concentration measure $C O N^{*}$ for which the relationship holds. This yields $C O N^{*}=-\beta_{1} / \beta_{3}$. We apply the Wald test to determine the joint significance of the two variables forming the total effect. Moreover, we compute joint standard errors for $O P E N$ and $O P E N \times C O N$, and use these to determine confidence bands around the turning points.

Table 22: presents the turning points calculated for each of the three regressions, along with their corresponding 10 percent confidence intervals. It also reports Wald test results for the joint significance of the openness variable and the interaction term. The Wald test statistics (column 3, Table 2 indicate that the total effect of openness on growth volatility is statistically significant at the $90 \%$ level or higher across specifications.

Table 2: Turning points with corresponding error bands for regressions using product concentration measures ${ }^{\dagger}$

\begin{tabular}{l|llll}
\hline \hline Indicator & Turning point & Joint significance & Confidence interval & Share \\
\hline Herfindahl & 0.154 & $9.03^{* * *}$ & {$[0.012,0.271]$} & 0.797 \\
5 product & 0.481 & $6.23^{* *}$ & {$[0.244,0.710]$} & 0.563 \\
10 product & 0.575 & $4.93^{*}$ & {$[0.289,0.905]$} & 0.469 \\
\hline \hline
\end{tabular}

Having computed joint standard errors for the two variables in question in order to determine confidence intervals, we can plot confidence bands around the total effect of trade openness on growth volatility. Figure $\overline{2}$ presents the plot for the 5 product index (specification G3) as an example. We can see that the impact of trade openness on growth volatility is significantly lower than zero with 90 percent confidence, as long as a country scores lower than about 0.24 on the concentration variable (Table $\overline{1} \overline{1}$ ). The effect gradually increases and changes sign (turning point) at about 0.48 . In contrast, above a value of about 0.71 , the impact of trade openness on growth volatility is significantly positive. A qualitatively equivalent illustration can be made for the 10 product and the Herfindahl indicators.

Let us put the value of 0.48 into context. It is straightforward to determine the share of countries in the sample whose value on the 5 product indicator lies below the turning point and the share of those whose value lies above it. We do so in Table 221 by cross-referencing the 


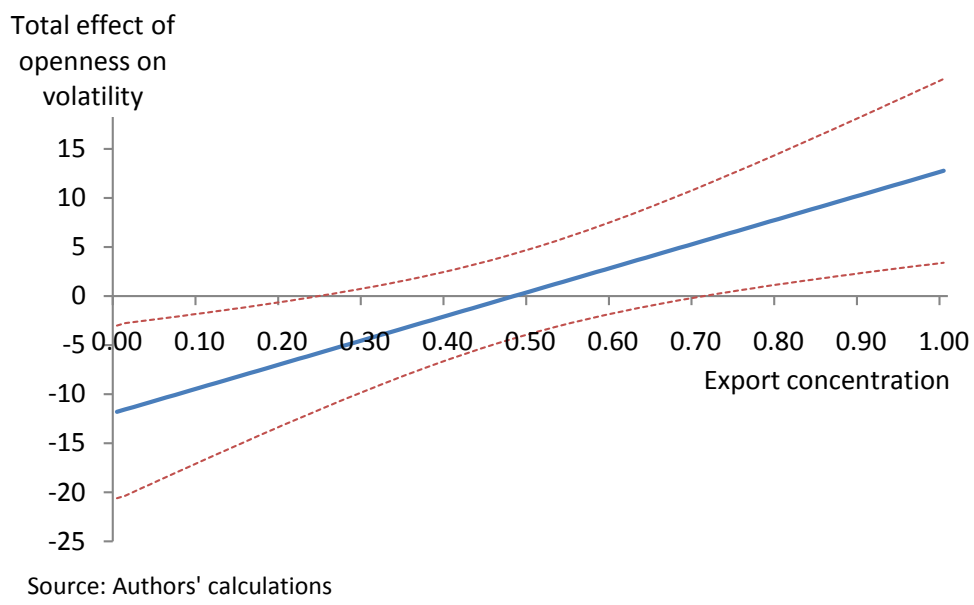

Figure 2: Total effect of concentration on growth volatility, for varying levels of openness, based on the 5 product index. The turning point of 0.48 has a 90 percent confidence band that includes fully positive values, along with parts of the distribution significantly above and below zero. 56 percent of countries in the final five year period fall under this level of concentration, indicating that increased openness will decrease their growth volatility.

turning points with the distribution of the concentration indicator during the last 5-year period (2000-2005) in our sample.

Table 2 in illustrates that the value of the 5 product measure lies below 0.48 for 56 percent of all countries. About half of the countries in our sample should thus, in principle, benefit from a marginal increase in trade openness by way of a reduction in their growth volatility. In the case of the 10 product indicator, we see a similar picture. The total effect of trade openness on growth volatility is again highly significant, and the system GMM estimator points to a turning point that lies at 0.58 , which is underscored by about 47 percent of countries (Table $\overline{2 i}$. For the Herfindahl indicator, this share of countries is even higher, at 80 percent. This, once again, suggests that a large share of the sample of countries benefits from trade openness in the sense that it reduces its income growth volatility.

\subsection{Robustness}

We perform a sequence of robustness checks to ensure the stability of our results.

As a first step, we experiment with the inclusion of additional controls (to the benchmark reported in Table 1 in that have been identified by the literature as potential (additional) determinants of growth volatility

\footnotetext{
${ }^{8}$ In the interest of saving space, we report results pertaining to only two product concentration indicatorsproduct Herfindahl and 5 product - noting that the results obtained from the 5 and 10 product indicators demonstrate significant overlap. In the tables discussed in this section (Appendix Tables columns refer to regressions using the product Herfindahl indicator, while even-numbered columns denote those using the 5 product indicator.
} 
growth rate $(E 3-E 4)$, a measure of human capital $(E 5-E 6)$, a measure of the volatility of government expenditure $(E 7-E 8)$, an indicator for the occurrence of natural disasters $(E 9-E 10)$ and, finally, population (E11-E12). Appendix Table interaction term and the openness variable continue to carry the correct signs and are statistically and economically significant, both individually (the interaction term) and jointly (the interaction term and the openness indicator), across all specifications. The estimated turning point estimates (not reported) are not markedly different from those found in our preferred benchmark in Table 2:" Moreover, while the coefficients on most newly-introduced variables are statistically insignificant, they tend to carry the expected signs. For instance, a fast-growing country is more likely to experience a reduction in its growth volatility; this is reasonable, since high-growth nations are more likely to enter into the league of high-income countries, which, as discussed before, have available to them more mechanisms for smoothing growth fluctuations. Greater volatility in government spending, in contrast, is detrimental for growth stability. An exception is population which is significant in the regressions and carries a negative sign. This result is consistent with the idea that larger economies - which tend to produce a wider range of products and have a larger domestic markets - experience lower growth volatility than smaller economies.

As a second step, we limit the sample to only low- and middle-income economies and as well as only middle- and high-income economies. The restriction allows us to tease out whether the contribution of diversification and openness to growth stability is driven by patterns in the developed or developing world. As can be seen in Appendix TableiA. markedly when high income economies are excluded from the analysis (columns $S 1$ and S2), although the sample size falls substantially. In contrast, when we exclude developing countries from the analysis (columns $S_{3}$ and $S_{4}$ ), the interaction term is significant only in one of the two regressions. Furthermore, while the variables of interest still carry the correct signs, the (statistical) significance of the relationship appears to be eroded. This suggests that much of the action driving our results indeed lies with low and middle income economies, for which export diversification matters more in shielding their economies from external shocks. A likely explanation is that developed economies have other means of insuring their economies against shocks, whereas developing countries depend more strongly on implicit insurance as represented by a more diversified structure in their exports.

We also explore various approaches to dealing with potential endogeneity in our setup. One approach was to employ external instruments as an alternative way of dealing with the issue of endogeneity in the trade openness variable. The literature has identified a reliable instrument for trade openness via the gravity-predicted trade flows (Frankel and $\bar{R}$ (Fmerni $\overline{9} \overline{9} \bar{j})$. We used this gravity-predicted variable as an instrument in a cross-sectional setup of our model, and confirmed our results under this setup. As an alternative approach, we take account of the concern that openness may also impact growth volatility through its effect on export concentration ( ( 
port baskets). We take explicit account of the relationship between openness and concentration by estimating a treatment effects model along the lines of Ranciêre, Tornell and Westermann

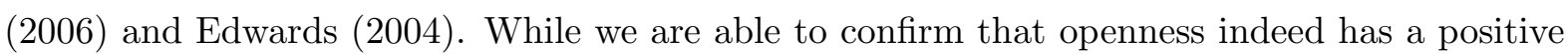
impact on product concentration, our other qualitative findings remain unchanged. The results for these additional tests, along with a variety of additional robustness checks - including basic specification changes, additional controls, alternative measures of key variables, and further sample restrictions - can be found in the Technical Appendix at the end of the paper.

\section{Conclusion}

This study addresses the mechanisms by which trade openness affects growth volatility. More specifically, we have sought to ascertain whether the effect of openness on growth volatility varies according to the extent of export concentration, as well whether there is a level of concentration below which - all else equal - greater openness is associated with a mitigating impact on volatility.

We find that the link between openness and growth volatility is indeed conditioned by the extent to which a country has diversified its export base. The results suggest that product diversification plays an important role in shielding an economy against the detrimental impact of idiosyncratic global shocks on volatility, while the evidence for market diversification is somewhat mixed. What is more, we were able to identify positive levels for product concentration measures at which the effect of openness on growth volatility switches sign. The results suggest that about half of the countries in our sample will experience reduced growth volatility should they choose to pursue increased openness to trade. These findings survive a range of additional robustness tests, including the inclusion of additional controls, alternative measures of key variables, the splitting of the sample into sub-groups of interest, and explicitly addressing several potential endogeneity concerns.

These results provide significant nuance to much of the existing understanding in academic research which was often aimed at finding evidence for or against a positive relationship between openness and volatility in large cross sections of countries. Crucially, policy advice that hews to greater or lesser trade liberalization, while disregarding a given economy's existing economic structure, may be seriously misguided. These findings are of major relevance for low-income countries that, for the most part, do not have very diversified export baskets.

\footnotetext{
${ }^{9}$ For instance, we calculate measures of export concentration at different levels of aggregation, and we deploy a combined measure of product-and-market concentration.
} 


\section{References}

Ahmed, S., "Sources of Economic Fluctuations in Latin America and Implications for Choice of Exchange Rate Regimes," Journal of Development Economics 72 (October 2003), 181-202.

Arellano, M. And S. R. Bond, "Some Tests of Specification for Panel Data: Monte Carlo Evidence and an Application to Employment Equations," Review of Economic Studies 58 (April 1991), 277-97.

Arellano, M. And O. Bover, "Another Look at the Instrumental Variable Estimation of Error-Components Models," Journal of Econometrics 68 (July 1995), 29-51.

Becker, T. I. And P. Mauro, "Output Drops and the Shocks that Matter," IMF Working Paper 06/172, International Monetary Fund, Washington, DC, 2006.

Bejan, M., "Trade Openness and Output Volatility," MPRA Paper 2759, University Library of Munich, Germany, 2006.

Bekaert, G., C. R. Harvey and C. Lundblad, "Growth Volatility and Financial Liberalization," Journal of International Money and Finance 25 (April 2006), 370-403.

Blundell, R. And S. R. Bond, "Initial Conditions and Moment Restrictions in Dynamic Panel Data Models," Journal of Econometrics 87 (August 1998), 115-143.

Bun, M. J. And F. WindmeiJer, "The Weak Instrument Problem of the System GMM Estimator in Dynamic Panel Data Models," Econometrics Journal 13(1) (2010), 95-126.

Calderón, C. A., N. V. Loayza and K. Schmidt-Hebbel, "Does Openness Imply Greater Exposure?," Policy Research Working Paper 3733, The World Bank, Washington, DC, 2005.

Cavallo, E. A., "Output Volatility and Openness to Trade: A Reassessment," Economía 9 (Fall 2008), $105-138$.

Channing, A., S. Jones And F. Tarp, "Aid, Growth, and Development: Have We Come Full Circle?," UNUWIDER Working Paper 2010/96 (2010).

Chinn, M. D. And H. Ito, "A New Measure of Financial Openness," Journal of Comparative Policy Analysis 10 (September 2008), 309-322.

Di Giovanni, J. And A. A. Levchenko, "Trade Openness and Volatility," Review of Economics and Statistics 91 (August 2009), 558-585.

Easterly, W. R. And A. C. KraAy, "Small States, Small Problems? Income, Growth, and Volatility in Small States," World Development 28 (November 2000), 2013-2027.

Edwards, S., "Financial Openness, Sudden Stops, and Current-Account Reversals," American Economic Review 94 (May 2004), 59-64.

Frankel, J. A. And D. H. Romer, "Does Trade Cause Growth?," American Economic Review 89 (June 1999), 379-399.

Freedom House, Freedom in the World: The Annual Survey of Political Rights and Civil Liberties, Rowman \& Littlefield, Lanham, MD (2009).

Jansen, M., "Income Volatility in Small and Developing Economies: Export Concentration Matters," WTO Discussion Paper 3, World Trade Organization, Geneva, Switzerland., 2004. 
Kose, M. A., E. S. Prasad, K. S. Rogoff and S.-J. Wei, "Financial Globalization: A Reappraisal," IMF Staff Papers 56 (April 2009), 8-62.

Loayza, N. V., R. T. RAncière, L. Servén And J. Ventura, "Macroeconomic Volatility and Welfare in Developing Countries: An Introduction," World Bank Economic Review 21 (October 2007), 343-57.

Marshall, M. G. and K. Jaggers, Polity IV Project: Political Regime Characteristics and Transitions, 18002008, Center for International Development and Conflict Management, College Park, MD, iv edition (2008).

Raddatz, C. E., "Are External Shocks Responsible for the Instability of Output in Low-Income Countries?," Journal of Development Economics 84 (September 2007), 155-187.

Ramey, G. AND V. A. RAmey, "Cross-Country Evidence on the Link between Volatility and Growth," American Economic Review 85 (December 1995), 1138-51.

Rancière, R. T., A. Tornell and F. Westermann, "Decomposing the Effects of Financial Liberalization: Crises vs. Growth," Journal of Banking and Finance 30 (December 2006), 3331-3348.

RoDrik, D., Has Globalization Gone Too Far? (Washington, DC: Institute for International Economics, 1997).

Sarkees, M. R. And P. Schafer, "The Correlates of War Data on War: An Update to 1997," Conflict Management and Peace Science 18 (February 2000), 123-144.

Windmeijer, F., "A Finite Sample Correction for the Variance of Linear Efficient Two-Step GMM Estimators," Journal of Econometrics 126 (May 2005), 25-51. 


\section{Appendix}

Table A.1: Sample of countries

\begin{tabular}{|c|c|}
\hline Algeria & Kenya \\
\hline Argentina & Madagascar \\
\hline Australia & Malawi \\
\hline Austria & Malaysia \\
\hline Bangladesh & Mexico \\
\hline Belgium & Morocco \\
\hline Bolivia & Netherlands \\
\hline Botswana & New Zealand \\
\hline Brazil & Nicaragua \\
\hline Burkina Faso & Niger \\
\hline Canada & Nigeria \\
\hline Chile & Norway \\
\hline China & Pakistan \\
\hline Colombia & Panama \\
\hline Congo, Dem. Rep. & Papua New Guinea \\
\hline Congo, Rep. & Paraguay \\
\hline Costa Rica & Peru \\
\hline Denmark & Philippines \\
\hline Dominican Rep & Portugal \\
\hline Ecuador & Senegal \\
\hline El Salvador & Sierra Leone \\
\hline Finland & Singapore \\
\hline France & South Africa \\
\hline Gambia, The & Spain \\
\hline Ghana & Sri Lanka \\
\hline Greece & Sweden \\
\hline Guatemala & Switzerland \\
\hline Haiti & Syria \\
\hline Honduras & Thailand \\
\hline Iceland & Togo \\
\hline India & Trinidad \& Tobago \\
\hline Indonesia & Tunisia \\
\hline Iran & Turkey \\
\hline Ireland & United Kingdom \\
\hline Israel & United States \\
\hline Italy & Uruguay \\
\hline Jamaica & Zambia \\
\hline Japan & Zimbabwe \\
\hline Jordan & \\
\hline
\end{tabular}




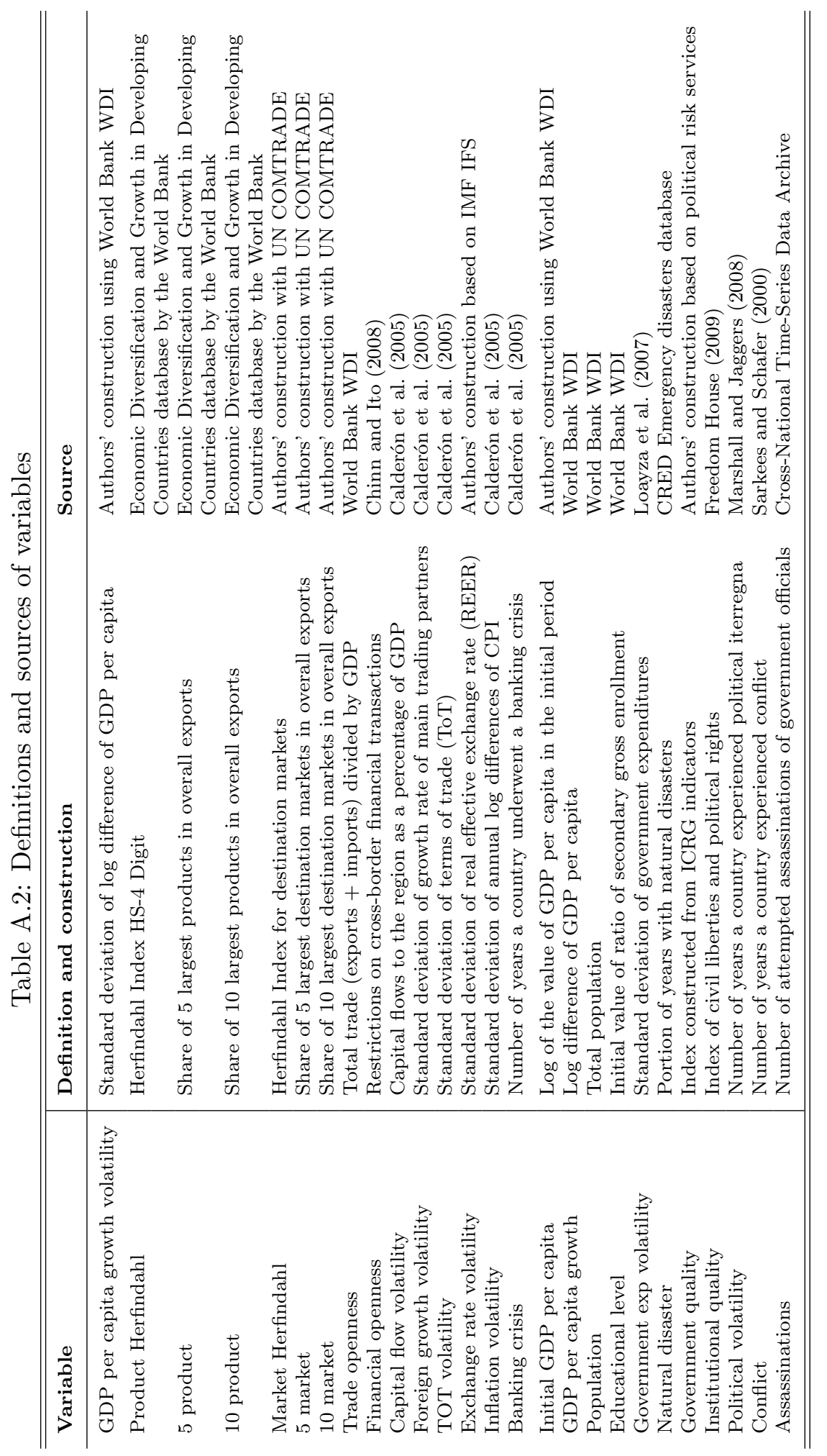


Table A.3: Summary statistics for main variables of interest

\begin{tabular}{l|lllll}
\hline \hline Variable & N & Mean & Std Dev & Min & Max \\
\hline $\begin{array}{l}\text { Growth volatility } \\
\text { Product concentration }\end{array}$ & 380 & 2.791 & 2.17 & 0.340 & 11.740 \\
$\quad$ Product Herfindahl & 378 & 0.139 & 0.17 & 0.007 & 0.919 \\
$\quad 5$ product & 378 & 0.504 & 0.25 & 0.100 & 0.987 \\
$\quad$ 10 product & 378 & 0.615 & 0.24 & 0.172 & 0.992 \\
Market concentration & & & & & \\
$\quad$ Market Herfindahl & 364 & 0.167 & 0.15 & 0.046 & 0.944 \\
$\quad 5$ market & 364 & 0.640 & 0.13 & 0.385 & 0.991 \\
$\quad 10$ market & 364 & 0.787 & 0.10 & 0.566 & 0.996 \\
\hline Trade openness & 380 & 0.803 & 0.11 & 0.450 & 1.157 \\
Financial openness & 380 & 0.198 & 1.53 & -1.798 & 2.540 \\
Capital flow volatility & 380 & 0.199 & 0.59 & -1.973 & 1.492 \\
Foreign growth volatility & 380 & -0.156 & 0.43 & -1.543 & 0.891 \\
Terms of trade volatility & 380 & 7.597 & 7.88 & 0.000 & 56.323 \\
Exchange rate volatility & 380 & $5,455.3$ & $103,633.7$ & 0.049 & $2,019,770$ \\
Inflation volatility & 380 & 8.819 & 20.81 & 0.191 & 168.127 \\
Banking crisis & 380 & 0.030 & 0.06 & 0.000 & 0.182 \\
\hline \hline
\end{tabular}

Table A.4: Correlation matrix for concentration indices

\begin{tabular}{l|llllll}
\hline \hline & $\begin{array}{l}\text { Product } \\
\text { Herf }\end{array}$ & $\begin{array}{l}5 \\
\text { product }\end{array}$ & $\begin{array}{l}10 \\
\text { product }\end{array}$ & $\begin{array}{l}\text { Market } \\
\text { Herf }\end{array}$ & $\begin{array}{l}5 \\
\text { market }\end{array}$ & $\begin{array}{l}10 \\
\text { market }\end{array}$ \\
\hline Product Herf & 1.000 & & & & & \\
5 product & 0.821 & 1.000 & & & & \\
10 product & 0.743 & 0.983 & 1.000 & & & \\
Market Herf & 0.240 & 0.226 & 0.233 & 1.000 & & \\
5 market & 0.450 & 0.460 & 0.457 & 0.815 & 1.000 & \\
10 market & 0.499 & 0.542 & 0.540 & 0.698 & 0.958 & 1.000 \\
\hline \hline
\end{tabular}


Table A.5: Percentile decompositions for concentration indices

\begin{tabular}{l|ll}
\hline \hline Percentile & Mean & Mean \\
\hline & Product Herfindahl & Market Herfindahl \\
$10 \%$ & 0.015 & 0.067 \\
$25 \%$ & 0.029 & 0.082 \\
$50 \%$ & 0.071 & 0.117 \\
$75 \%$ & 0.190 & 0.184 \\
$90 \%$ & 0.346 & 0.333 \\
\hline & 5 product & 5 market \\
$10 \%$ & 0.197 & 0.480 \\
$25 \%$ & 0.292 & 0.530 \\
$50 \%$ & 0.476 & 0.630 \\
$75 \%$ & 0.707 & 0.723 \\
$90 \%$ & 0.879 & 0.831 \\
\hline & 10 product & 10 market \\
$10 \%$ & 0.295 & 0.652 \\
$25 \%$ & 0.410 & 0.705 \\
$50 \%$ & 0.614 & 0.787 \\
$75 \%$ & 0.825 & 0.869 \\
$90 \%$ & 0.948 & 0.930 \\
\hline \hline
\end{tabular}




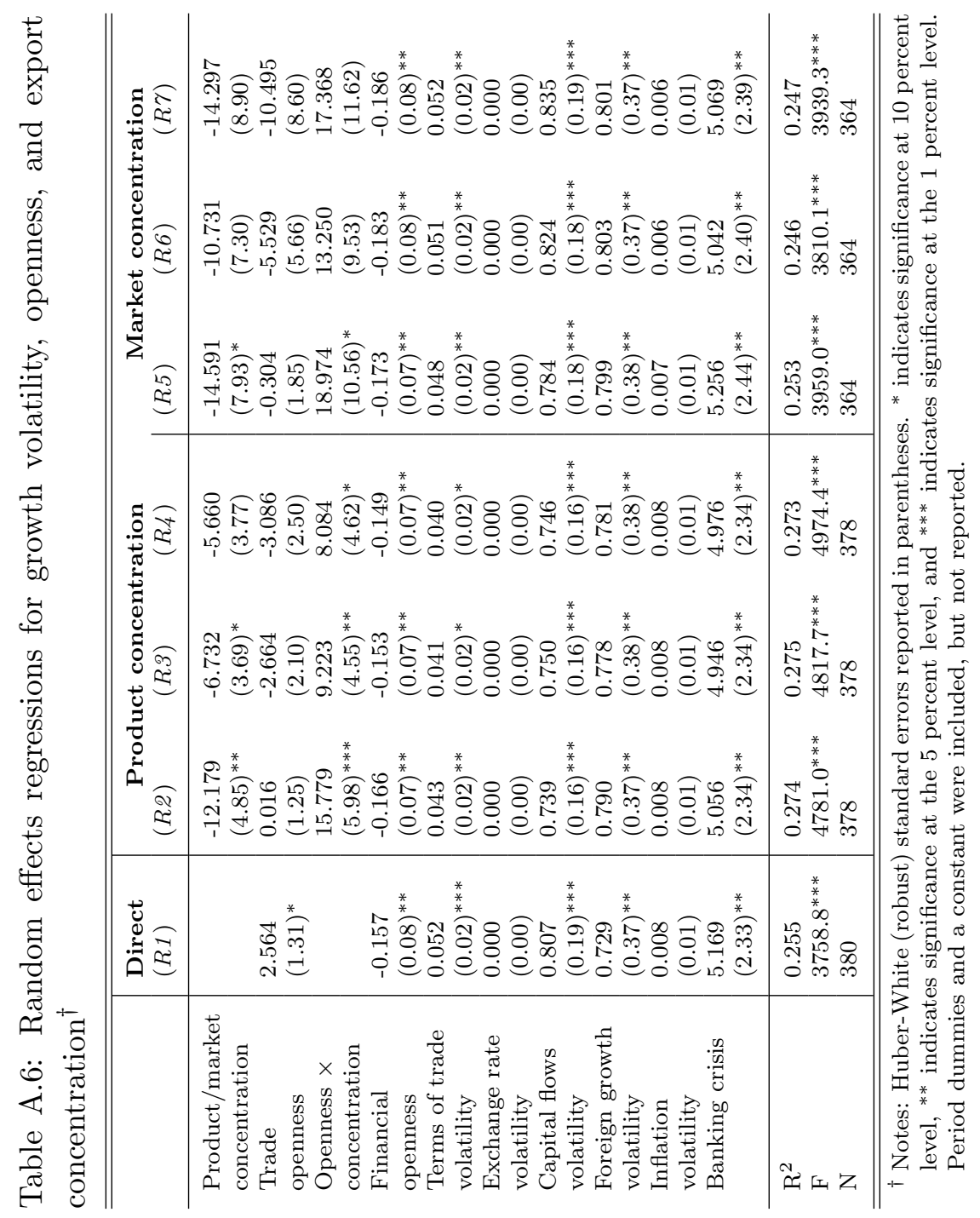




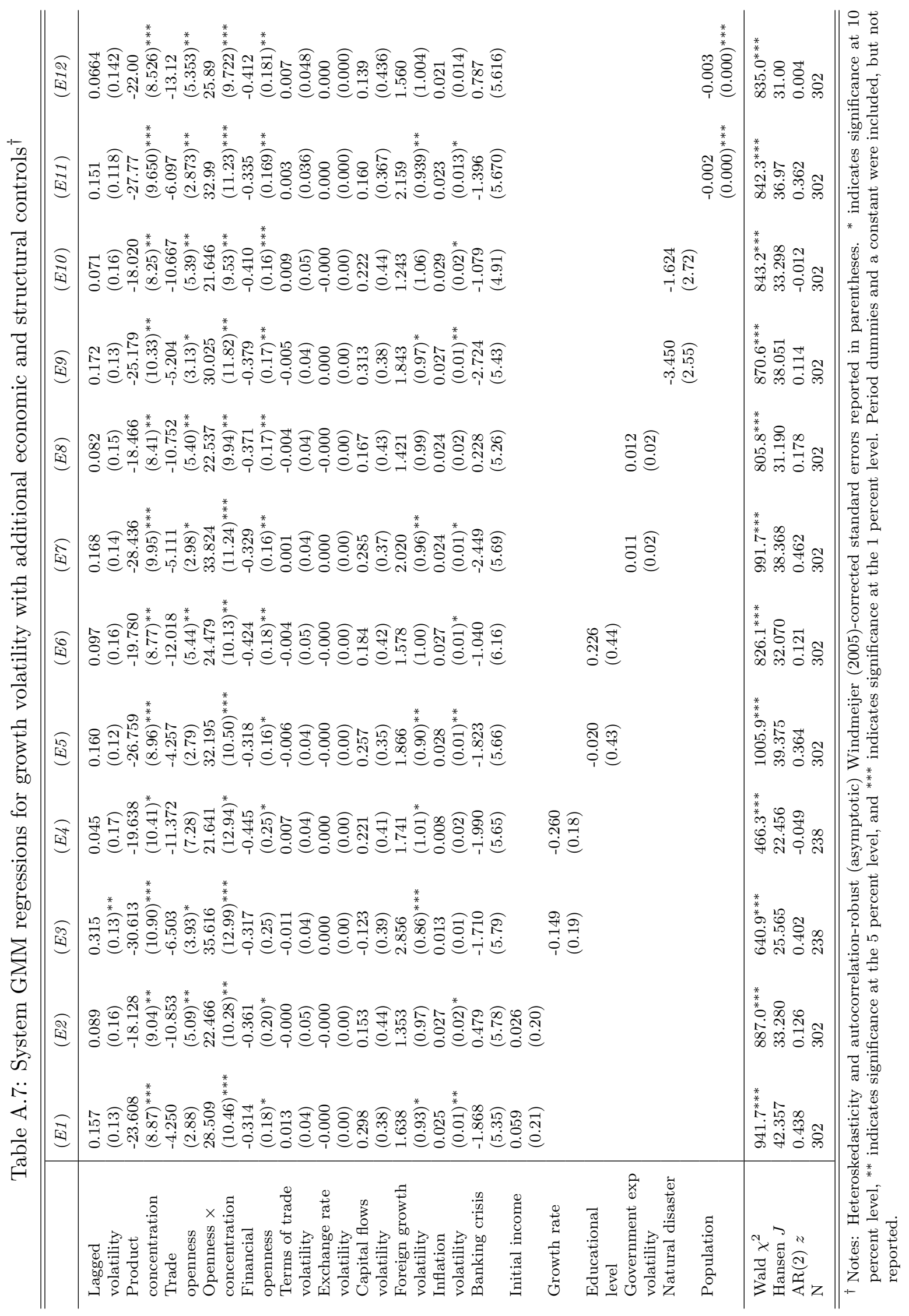


Table A.8: System GMM regressions for growth volatility for selected subsamples ${ }^{\dagger}$

\begin{tabular}{|c|c|c|c|c|}
\hline & \multicolumn{2}{|c|}{$\begin{array}{l}\text { Low/middle income } \\
(S 1) \quad(S 2)\end{array}$} & \multicolumn{2}{|c|}{$\begin{array}{l}\text { High/middle income } \\
(S 3) \quad\left(S_{4}\right)\end{array}$} \\
\hline $\begin{array}{l}\text { Lagged } \\
\text { volatility } \\
\text { Product }\end{array}$ & $\begin{array}{l}0.251 \\
(0.13)^{* *} \\
-21.973\end{array}$ & $\begin{array}{l}0.300 \\
(0.15)^{*} \\
-25.074\end{array}$ & $\begin{array}{l}0.074 \\
(0.14) \\
-37.768\end{array}$ & $\begin{array}{l}-0.006 \\
(0.15) \\
-5.390\end{array}$ \\
\hline concentration & $(8.91)^{* *}$ & $(9.85)^{* *}$ & $(12.00)^{* * *}$ & $(8.65)$ \\
\hline Trade & -5.079 & -16.994 & -3.776 & -2.959 \\
\hline openness & $(3.75)$ & $(7.10)^{* *}$ & $(3.10)$ & $(4.80)$ \\
\hline Openness $\times$ & 25.274 & 29.756 & 40.959 & 6.141 \\
\hline concentration & $(10.48)^{* *}$ & $(11.55)^{* *}$ & $(12.84)^{* * *}$ & $(10.81)$ \\
\hline Financial & -0.378 & -0.155 & -0.550 & -0.581 \\
\hline openness & $(0.19)^{* *}$ & $(0.21)$ & $(0.17)^{* * *}$ & $(0.17)^{* * *}$ \\
\hline Capital flows & 0.805 & 0.907 & 0.369 & 0.304 \\
\hline volatility & $(0.47)^{*}$ & $(0.46)^{* *}$ & $(0.32)$ & $(0.38)$ \\
\hline Foreign growth & 2.732 & 2.863 & 1.076 & 1.266 \\
\hline volatility & $(1.02)^{* * *}$ & $(1.08)^{* * *}$ & $(0.87)$ & $(1.10)$ \\
\hline Terms of trade & 0.020 & 0.018 & 0.046 & 0.011 \\
\hline volatility & $(0.04)$ & $(0.05)$ & $(0.06)$ & $(0.05)$ \\
\hline Exchange rate & 0.000 & 0.000 & -0.000 & 0.000 \\
\hline volatility & $(0.00)$ & $(0.00)$ & $(0.00)$ & $(0.00)$ \\
\hline Inflation & 0.012 & 0.006 & 0.018 & 0.017 \\
\hline volatility & $(0.01)$ & $(0.01)$ & $(0.01)$ & $(0.01)$ \\
\hline Banking crisis & -0.970 & 2.857 & -2.573 & -5.687 \\
\hline & $(5.55)$ & $(5.95)$ & $(3.85)$ & $(3.70)$ \\
\hline Wald $\chi^{2}$ & $522.7^{* * *}$ & $779.3^{* * *}$ & $775.0^{* * *}$ & $830.3^{* * *}$ \\
\hline Hansen $J$ & 37.677 & 28.957 & 35.547 & 35.771 \\
\hline $\operatorname{AR}(2) z$ & 0.881 & 0.814 & 0.935 & 1.028 \\
\hline $\mathrm{N}$ & 207 & 207 & 231 & 231 \\
\hline
\end{tabular}

${ }^{\dagger}$ Notes: Heteroskedasticity and autocorrelation-robust (asymptotic) ${ }_{1}^{+}=-=-1$ Wind-

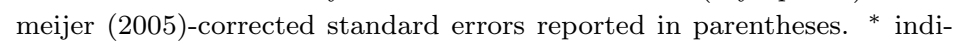
cates significance at 10 percent level, ${ }^{* *}$ indicates significance at the 5 percent level, and ${ }^{* * *}$ indicates significance at the 1 percent level. Period dummies and a constant were included, but not reported. 


\section{Technical Appendix}

In this Technical Appendix, we report additional summary statistics and a sequence of robustness checks. In the interest of saving space, and noting that the results based on the 5-product and 10-product indicators are typically very similar, we report only regressions based on the Herfindahl and 5-product indices. We discuss differences between the 5-product and 10-product estimators when they arise, and results based on the 10 product indicator are available upon request. In general, and unless otherwise indicated, results based on the Herfindahl index are reported in odd numbered columns, and results based on the 5 product index are reported in even numbered columns.

\section{Summary statistics}

Table the final five-year period.

Table B.1: Summary statistics for key explanatory variables in the final five-year period

\begin{tabular}{|c|c|c|c|c|c|c|c|c|c|c|c|c|}
\hline & Percentile & $\mathbf{N}$ & Mean & Std Dev & Min & $\operatorname{Max}$ & Percentile & $\mathbf{N}$ & Mean & Std Dev & Min & $\operatorname{Max}$ \\
\hline & \multicolumn{6}{|c|}{ Product Herfindahl } & \multicolumn{6}{|c|}{ Market Herfindahl } \\
\hline $10 \%$ & 0.016 & 64 & 0.120 & 0.17 & 0.008 & 0.819 & 0.067 & 64 & 0.155 & 0.14 & 0.052 & 0.755 \\
\hline $25 \%$ & 0.029 & & & & & & 0.083 & & & & & \\
\hline $50 \%$ & 0.051 & & & & & & 0.112 & & & & & \\
\hline $75 \%$ & 0.127 & & & & & & 0.175 & & & & & \\
\hline \multirow[t]{2}{*}{$90 \%$} & 0.312 & & & & & & 0.236 & & & & & \\
\hline & \multicolumn{6}{|c|}{5 product } & \multicolumn{6}{|c|}{5 market } \\
\hline $10 \%$ & 0.204 & 64 & 0.464 & 0.22 & 0.132 & 0.974 & 0.487 & 64 & 0.630 & 0.12 & 0.409 & 0.966 \\
\hline $25 \%$ & 0.293 & & & & & & 0.531 & & & & & \\
\hline $50 \%$ & 0.415 & & & & & & 0.615 & & & & & \\
\hline $75 \%$ & 0.612 & & & & & & 0.712 & & & & & \\
\hline \multirow[t]{2}{*}{$90 \%$} & 0.769 & & & & & & 0.783 & & & & & \\
\hline & \multicolumn{6}{|c|}{10 product } & \multicolumn{6}{|c|}{10 market } \\
\hline $10 \%$ & 0.309 & 64 & 0.577 & 0.21 & 0.212 & 0.983 & 0.100 & 64 & 0.777 & 0.10 & 0.566 & 0.989 \\
\hline $25 \%$ & 0.395 & & & & & & 0.250 & & & & & \\
\hline $50 \%$ & 0.581 & & & & & & 0.500 & & & & & \\
\hline $75 \%$ & 0.755 & & & & & & 0.750 & & & & & \\
\hline \multirow[t]{2}{*}{$90 \%$} & 0.828 & & & & & & 0.900 & & & & & \\
\hline & \multicolumn{6}{|c|}{ Openness } & & & & & & \\
\hline $10 \%$ & 0.684 & 64 & 0.841 & 0.11 & 0.618 & 1.133 & & & & & & \\
\hline $25 \%$ & 0.791 & & & & & & & & & & & \\
\hline $50 \%$ & 0.857 & & & & & & & & & & & \\
\hline $75 \%$ & 0.898 & & & & & & & & & & & \\
\hline $90 \%$ & 0.950 & & & & & & & & & & & \\
\hline
\end{tabular}


Table $\overline{\mathrm{B}} \overline{\mathrm{A}} \overline{\mathrm{i}}$ provides average concentration index values for the last five-year period in the sample.

Table B.2: Average concentration index values in final 5-year period ${ }^{\dagger}$

\begin{tabular}{|c|c|c|c|c|c|c|}
\hline Country & $\begin{array}{l}\text { Product } \\
\text { Herfindahl }\end{array}$ & $\begin{array}{l}5 \\
\text { Product }\end{array}$ & $\begin{array}{l}10 \\
\text { Product }\end{array}$ & $\begin{array}{l}\text { Market } \\
\text { Herfindahl }\end{array}$ & $\begin{array}{l}5 \\
\text { Market }\end{array}$ & $\begin{array}{l}10 \\
\text { Market }\end{array}$ \\
\hline Algeria & 0.444 & 0.958 & 0.983 & 0.119 & 0.695 & 0.894 \\
\hline Argentina & 0.035 & 0.355 & 0.492 & 0.072 & 0.509 & 0.651 \\
\hline Australia & 0.035 & 0.326 & 0.488 & 0.078 & 0.536 & 0.707 \\
\hline Bangladesh & 0.088 & 0.616 & 0.788 & 0.154 & 0.683 & 0.837 \\
\hline Belgium & 0.024 & 0.279 & 0.345 & 0.099 & 0.637 & 0.779 \\
\hline Bolivia & 0.105 & 0.583 & 0.753 & 0.151 & 0.735 & 0.890 \\
\hline Botswana & 0.632 & 0.935 & 0.969 & 0.643 & 0.966 & 0.989 \\
\hline Brazil & 0.016 & 0.197 & 0.317 & 0.073 & 0.442 & 0.595 \\
\hline Burkina Faso & 0.396 & 0.753 & 0.821 & 0.245 & 0.819 & 0.938 \\
\hline Canada & 0.033 & 0.338 & 0.425 & 0.738 & 0.914 & 0.941 \\
\hline Chile & 0.108 & 0.538 & 0.659 & 0.071 & 0.487 & 0.683 \\
\hline China & 0.012 & 0.180 & 0.277 & 0.102 & 0.607 & 0.720 \\
\hline Colombia & 0.068 & 0.474 & 0.578 & 0.206 & 0.653 & 0.759 \\
\hline Costa Rica & 0.127 & 0.598 & 0.686 & 0.236 & 0.650 & 0.794 \\
\hline Denmark & 0.013 & 0.204 & 0.279 & 0.071 & 0.504 & 0.711 \\
\hline Dominican Rep & 0.051 & 0.398 & 0.579 & 0.205 & 0.764 & 0.878 \\
\hline Ecuador & 0.246 & 0.769 & 0.825 & 0.209 & 0.694 & 0.836 \\
\hline El Salvador & 0.069 & 0.485 & 0.613 & 0.153 & 0.783 & 0.917 \\
\hline France & 0.016 & 0.230 & 0.304 & 0.065 & 0.512 & 0.687 \\
\hline Gambia, The & 0.127 & 0.609 & 0.758 & 0.214 & 0.820 & 0.931 \\
\hline Ghana & 0.202 & 0.681 & 0.828 & 0.096 & 0.588 & 0.780 \\
\hline Guatemala & 0.042 & 0.392 & 0.559 & 0.175 & 0.720 & 0.846 \\
\hline Honduras & 0.081 & 0.503 & 0.690 & 0.201 & 0.728 & 0.849 \\
\hline India & 0.028 & 0.256 & 0.344 & 0.057 & 0.409 & 0.566 \\
\hline Indonesia & 0.027 & 0.292 & 0.393 & 0.090 & 0.568 & 0.724 \\
\hline Iran & 0.691 & 0.882 & 0.901 & 0.199 & 0.844 & 0.914 \\
\hline Ireland & 0.057 & 0.447 & 0.616 & 0.112 & 0.658 & 0.834 \\
\hline Israel & 0.142 & 0.508 & 0.596 & 0.162 & 0.584 & 0.721 \\
\hline Italy & 0.008 & 0.132 & 0.212 & 0.058 & 0.484 & 0.618 \\
\hline Japan & 0.032 & 0.294 & 0.397 & 0.103 & 0.573 & 0.726 \\
\hline Jordan & 0.051 & 0.432 & 0.644 & 0.117 & 0.623 & 0.761 \\
\hline Kenya & 0.080 & 0.518 & 0.623 & 0.069 & 0.507 & 0.672 \\
\hline Madagascar & 0.112 & 0.637 & 0.789 & 0.225 & 0.777 & 0.887 \\
\hline Malawi & 0.312 & 0.811 & 0.884 & 0.075 & 0.540 & 0.732 \\
\hline Malaysia & 0.043 & 0.365 & 0.499 & 0.093 & 0.585 & 0.761 \\
\hline Mexico & 0.029 & 0.303 & 0.433 & 0.755 & 0.919 & 0.944 \\
\hline Morocco & 0.030 & 0.298 & 0.480 & 0.153 & 0.669 & 0.807 \\
\hline Netherlands & 0.010 & 0.167 & 0.238 & 0.095 & 0.598 & 0.738 \\
\hline New Zealand & 0.031 & 0.320 & 0.464 & 0.084 & 0.555 & 0.686 \\
\hline Nicaragua & 0.055 & 0.443 & 0.647 & 0.160 & 0.716 & 0.879 \\
\hline Nigeria & 0.819 & 0.974 & 0.983 & 0.168 & 0.666 & 0.823 \\
\hline Norway & 0.256 & 0.699 & 0.759 & 0.097 & 0.603 & 0.812 \\
\hline Pakistan & 0.050 & 0.396 & 0.583 & 0.084 & 0.492 & 0.644 \\
\hline Panama & 0.052 & 0.382 & 0.482 & 0.255 & 0.690 & 0.812 \\
\hline Paraguay & 0.170 & 0.682 & 0.815 & 0.155 & 0.707 & 0.848 \\
\hline Peru & 0.077 & 0.528 & 0.664 & 0.105 & 0.537 & 0.694 \\
\hline Philippines & 0.132 & 0.590 & 0.691 & 0.111 & 0.629 & 0.863 \\
\hline Portugal & 0.019 & 0.231 & 0.347 & 0.115 & 0.669 & 0.839 \\
\hline Senegal & 0.095 & 0.556 & 0.712 & 0.114 & 0.603 & 0.789 \\
\hline South Africa & 0.031 & 0.351 & 0.466 & 0.052 & 0.444 & 0.589 \\
\hline Spain & 0.029 & 0.265 & 0.332 & 0.083 & 0.590 & 0.725 \\
\hline Sri Lanka & 0.041 & 0.351 & 0.503 & 0.163 & 0.635 & 0.755 \\
\hline Sweden & 0.017 & 0.230 & 0.327 & 0.055 & 0.443 & 0.680 \\
\hline Syria & 0.431 & 0.772 & 0.825 & 0.147 & 0.667 & 0.821 \\
\hline Thailand & 0.016 & 0.212 & 0.309 & 0.075 & 0.516 & 0.682 \\
\hline Togo & 0.109 & 0.637 & 0.752 & 0.092 & 0.594 & 0.742 \\
\hline Trinidad \& Tobago & 0.173 & 0.723 & 0.785 & 0.327 & 0.737 & 0.828 \\
\hline Tunisia & 0.037 & 0.357 & 0.503 & 0.175 & 0.747 & 0.884 \\
\hline Turkey & 0.015 & 0.198 & 0.309 & 0.055 & 0.445 & 0.620 \\
\hline United Kingdom & 0.017 & 0.238 & 0.337 & 0.067 & 0.508 & 0.694 \\
\hline United States & 0.011 & 0.177 & 0.255 & 0.086 & 0.521 & 0.671 \\
\hline Uruguay & 0.040 & 0.349 & 0.469 & 0.088 & 0.527 & 0.703 \\
\hline Zambia & 0.255 & 0.766 & 0.881 & 0.194 & 0.762 & 0.892 \\
\hline Zimbabwe & 0.093 & 0.541 & 0.657 & 0.096 & 0.539 & 0.724 \\
\hline
\end{tabular}

$\dagger$ Notes: 5-year period beginning 2001-2005, inclusive. 


\section{Political and institutional controls}

We add political and institutional control variables to the main specification. These are: measures of government $(P 1-P 2)$ and institutional quality $\left(P_{3}-P_{4}\right)$, and indicators of political volatility $(P 5-P 6)$, civil conflict $\left(P^{r}-P 8\right)$, and assassinations of public officials $(P 9-P 10)$.

The results are reported in Table variables, the main results of the paper hold. The coefficients of the newly-introduced variables are statistically insignificant but they tend to carry the expected signs. For instance, superior government and institutional quality $(P 1-P 4)$ exert a moderating effect on volatility, while the presence of civil conflict $\left(P^{r}-P 8\right)$ has the opposite effect. 


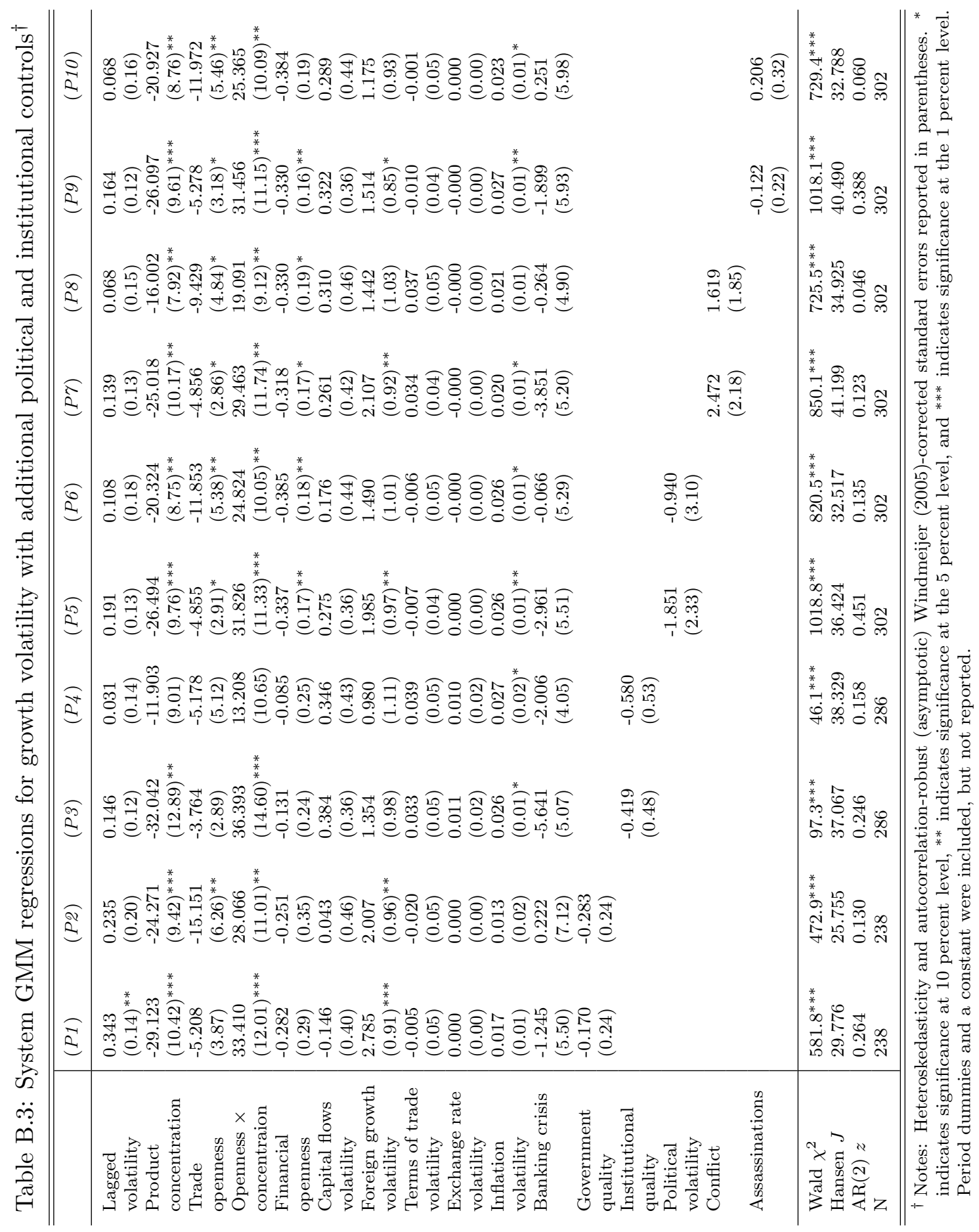




\section{Subsample analysis}

We restrict the sample from either end by deleting the final (2001-2005) (Table B. S1 and S2) and first (1976-1980) (Table IB.4. $_{\text {S }} 3$ and S4) periods from the sample. The first restriction, which deletes the most recent period, examines the importance of recent history in influencing the outcomes of the analysis. The second, which pares the earliest period of the sample, tests the robustness to the exclusion of the period of increased global trade integration in the late 1970s and early 1980s, which followed the end of the Tokyo Round and led up to the important Uruguay Round of the GATT

The results for specifications $S_{3}$ and $S_{4}$ show that excluding the first five-year period does not change the results in any noteworthy way. The coefficients of our variables of interest carry the expected signs and the interaction terms are highly significant. Instead, when we delete the last period the interaction term between the 5 product and trade openness is insignificant at the 10 percent level (column S2). Although these results do not change our main conclusions, they emphasize the importance of recent changes in the global pattern of trade liberalization and diversification since the turn of the 21st century, when the world economy experienced an extended period of economic calm.

\footnotetext{
${ }^{10}$ Restricting the sample further by eliminating the first two periods yields qualitatively similar results.
} 
Table B.4: System GMM regressions for growth volatility for selected subsamples ${ }^{\dagger}$

\begin{tabular}{|c|c|c|c|c|}
\hline & \multicolumn{2}{|c|}{ 1976-2000 } & \multicolumn{2}{|c|}{ 1981-2005 } \\
\hline & $(S 1)$ & $(S 2)$ & $(S 3)$ & $\left(S_{4}\right)$ \\
\hline \multirow{6}{*}{$\begin{array}{l}\text { Lagged } \\
\text { volatility } \\
\text { Product } \\
\text { concentration } \\
\text { Trade } \\
\text { openness }\end{array}$} & 0.329 & 0.126 & 0.175 & 0.113 \\
\hline & $(0.13)^{* *}$ & $(0.17)$ & & $(0.16)$ \\
\hline & -29.447 & -18. & -27 . & -21. \\
\hline & $(11.23)^{* * *}$ & $(11.9$ & $(10.01)^{* * *}$ & $(8.3$ \\
\hline & -7.407 & & -6.545 & \\
\hline & $(3.78)^{* *}$ & $(7.5$ & $(3.52)^{*}$ & )$^{* *}$ \\
\hline \multirow{4}{*}{$\begin{array}{l}\text { Openness } \times \\
\text { concentration } \\
\text { Financial } \\
\text { openness }\end{array}$} & 34.604 & 21.805 & 33.358 & 26.128 \\
\hline & $(13.26)^{* * *}$ & $(14.34)$ & $(11.76)^{* * *}$ & $(9.69)^{* * *}$ \\
\hline & -0.407 & -0.5 & -0.303 & \\
\hline & $(0.27)$ & $(0.30)^{*}$ & $(0.17)^{*}$ & $(0.18)^{* *}$ \\
\hline \multirow{4}{*}{$\begin{array}{l}\text { Capital flows } \\
\text { volatility } \\
\text { Foreign growth } \\
\text { volatility }\end{array}$} & -0.281 & -0.1 & 0.228 & 0.208 \\
\hline & $(0.41)$ & $(0.46)$ & $(0.37)$ & $(0.44)$ \\
\hline & 2.938 & 2.14 & 2.037 & 1.556 \\
\hline & $(0.92)^{* * *}$ & $(1.09)^{* *}$ & $(0.94)^{* *}$ & $(0.98)$ \\
\hline \multirow{2}{*}{$\begin{array}{l}\text { Terms of trade } \\
\text { volatility }\end{array}$} & -0.013 & -0.016 & -0.005 & -0.004 \\
\hline & $(0.05)$ & $(0.05)$ & $(0.04)$ & $(0.05)$ \\
\hline \multirow{2}{*}{$\begin{array}{l}\text { Exchange rate } \\
\text { volatility }\end{array}$} & 0.000 & 0.000 & 0.000 & 0.000 \\
\hline & $(0.00)$ & $(0.00)$ & $(0$. & \\
\hline \multirow{2}{*}{$\begin{array}{l}\text { Inflation } \\
\text { volatility }\end{array}$} & 0.017 & 0.016 & 0.026 & 0.025 \\
\hline & $(0.01)$ & $(0.02)$ & $(0.01)^{* *}$ & $(0.01)^{*}$ \\
\hline \multirow[t]{2}{*}{ Banking crisis } & -1.119 & -1.270 & -2.395 & -0.220 \\
\hline & $(5.64)$ & & $(5.85)$ & \\
\hline \multirow{4}{*}{$\begin{array}{l}\text { Wald } \chi^{2} \\
\text { Hansen } J \\
\operatorname{AR}(2) z \\
\mathrm{~N}\end{array}$} & $587.5^{* * *}$ & $463.1^{\text {*** }}$ & $778.2^{* * *}$ & $806.9^{* * *}$ \\
\hline & 24.855 & 21.798 & 37.788 & 30.593 \\
\hline & 0.470 & 0.267 & 0.421 & 0.154 \\
\hline & 238 & 238 & 283 & 283 \\
\hline \multicolumn{5}{|c|}{ 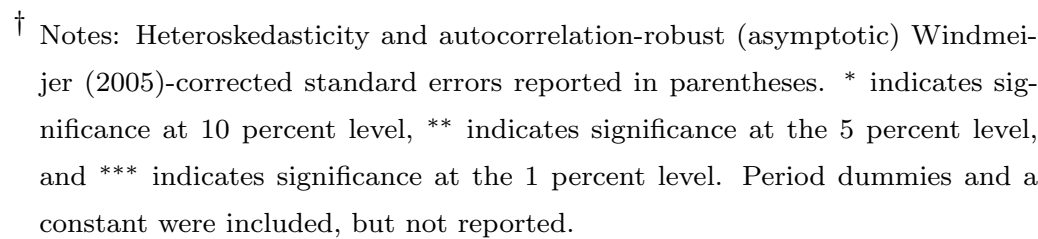 } \\
\hline
\end{tabular}




\section{Using external instruments to further address endogeneity concerns}

We explore using external instruments as an alternative way of dealing with the issue of endogeneity in our setup. The literature has identified a reliable instrument for trade openness in the gravity-predicted trade flow variable of 'Frankel and Romeri (i $1 \overline{9} \overline{9} \overline{9})$. We employ this instrument for the analysis that follows. We begin our exploration by attempting to use the gravity predicted variable as an instrument in a cross-sectional setup; it is used to instrument both for the trade openness variable itself as well as for the interaction term. The specification is otherwise equivalent to the setup used above in our benchmark specification. The model is estimated for each of the five-year periods in our sample separately. We directly test for the endogeneity of the trade openness variable using the Durbin-Wu-Hausman test: of the six 5-year periods, the test fails to reject the null hypothesis of exogeneity for four of the five-year periods at the 5 percent level (rejections occur in the first and final 5-year period, and in the first the sample size of 18 makes it difficult to draw strong inference). Moreover, the Stock-Yogo tests suggest that the cross-sectional IVs suffer from weak instrument problems in our setup.

Although the results of the estimations are mostly qualitatively similar to the ones in our benchmark regressions, we prefer incorporating the Frankel-Romer instrument into the benchmark system GMM regressions as an additional external instrument; an added benefit, of course, is that we thereby avoid efficiency losses resulting from reducing the panel to a cross-sectional data set. Doing so does not alter our earlier findings in any substantial way (the findings, for specifications analogous to the main specifications, are reported in Table $\bar{B} \overline{\mathrm{B}} . \overline{\mathrm{5}} \mathbf{1})$. The variables of interest generally retain their signs and both statistical and economic significance. 
Table B.5: System GMM regressions for growth volatility with additional external instruments $^{\dagger}$

\begin{tabular}{|c|c|c|}
\hline & $\begin{array}{l}\text { Product div } \\
(\text { Herfindahl) }\end{array}$ & $\begin{array}{r}\text { ersification } \\
(5 \text { Product })\end{array}$ \\
\hline $\begin{array}{l}\text { Lagged } \\
\text { volatility } \\
\text { Product } \\
\text { concentration } \\
\text { Trade } \\
\text { openness } \\
\text { Openness } \times \\
\text { concentration } \\
\text { Financial } \\
\text { openness } \\
\text { Terms of trade } \\
\text { volatility } \\
\text { Exchange rate } \\
\text { volatility } \\
\text { Capital flows } \\
\text { volatility } \\
\text { Foreign growth } \\
\text { volatility } \\
\text { Inflation } \\
\text { volatility } \\
\text { Banking crisis }\end{array}$ & $\begin{array}{l}0.157 \\
(0.12) \\
-19.482 \\
(9.14)^{* *} \\
-0.040 \\
(2.06) \\
22.750 \\
(10.78)^{* *} \\
-0.401 \\
(0.16)^{* *} \\
0.000 \\
(0.04) \\
0.000 \\
(0.00) \\
0.440 \\
(0.37) \\
1.736 \\
(0.90)^{*} \\
0.024 \\
(0.01)^{* *} \\
-3.790 \\
(5.51)\end{array}$ & $\begin{array}{l}0.108 \\
(0.14) \\
-13.814 \\
(7.12)^{*} \\
-4.706 \\
(3.94) \\
16.734 \\
(8.50)^{* *} \\
-0.421 \\
(0.17)^{* *} \\
0.005 \\
(0.05) \\
-0.000 \\
(0.00) \\
0.290 \\
(0.45) \\
1.211 \\
(1.01) \\
0.025 \\
(0.01)^{*} \\
-2.271 \\
(4.93)\end{array}$ \\
\hline $\begin{array}{l}\text { Wald } \chi^{2} \\
\text { Hansen } J \\
\operatorname{AR}(2) z \\
\mathrm{~N}\end{array}$ & $\begin{array}{l}1034.5^{* * *} \\
38.064 \\
0.372 \\
302\end{array}$ & $\begin{array}{l}961.6^{* * *} \\
35.640 \\
0.232 \\
302\end{array}$ \\
\hline
\end{tabular}

$\dagger$ Notes: Heteroskedasticity and autocorrelationrobust (asymptotic) "Windmeijer" (2005)corrected standard errors reported in parentheses. ${ }^{*}$ indicates significance at 10 percent level, ** indicates significance at the 5 percent level, and ${ }^{* * *}$ indicates significance at the 1 percent level. Period dummies and a constant were included, but not reported. 


\section{Nonlinearity in the interaction term}

We test for nonlinearity in the interaction term by interacting the openness measure with both the linear and the quadratic indicator of export product concentration. In general, when an interaction term is included in a regression both variables that compose it are included as well. In this case, we do not include the quadratic index of export concentration as a regressor because this leads to a general loss of significance due to the high multicollinearity.

In Table $1 \bar{B} \cdot \overline{6}$, we report the results of the GMM estimates of the benchmark model augmented by the additional interaction variable given by the product between the openness measure and the quadratic indicator of export product concentration. The results show that the interaction variable between trade openness and export concentration squared is not significant. This suggests that that the interaction between export concentration and growth volatility is not nonlinear in the openness measure.

Table B.6: System GMM regressions for growth volatility, openness, and concentration to test for potential non-linearity in the interaction term ${ }^{\dagger}$

\begin{tabular}{|c|c|c|}
\hline & $(N L 1)$ & (NL2) \\
\hline Lagged volatility & $\begin{array}{c}0.259 \\
(0.111)^{* *}\end{array}$ & $\begin{array}{c}0.154 \\
(0.166)\end{array}$ \\
\hline Product concentration & $\begin{array}{c}-25.09 \\
(10.35)^{* *}\end{array}$ & $\begin{array}{c}-15.18 \\
(8.418)^{*}\end{array}$ \\
\hline Openness $\times$ concentration & $\begin{array}{c}29.72 \\
(10.81)^{* * *}\end{array}$ & $\begin{array}{c}21.27 \\
(12.83)^{*}\end{array}$ \\
\hline Openness $\times$ concentration ${ }^{2}$ & $\begin{array}{c}1.515 \\
(5.513)\end{array}$ & $\begin{array}{l}-2.027 \\
(4.562)\end{array}$ \\
\hline Trade openness & $\begin{array}{c}-5.144 \\
(3.065)^{*}\end{array}$ & $\begin{array}{c}-9.769 \\
(5.508)^{*}\end{array}$ \\
\hline Financial openness & $\begin{array}{c}-0.281 \\
(0.152)^{*}\end{array}$ & $\begin{array}{l}-0.297 \\
(0.187)\end{array}$ \\
\hline Capital flows volatility & $\begin{array}{c}0.202 \\
(0.347)\end{array}$ & $\begin{array}{c}0.180 \\
(0.366)\end{array}$ \\
\hline Foreign growth volatility & $\begin{array}{c}1.411 \\
(0.891)\end{array}$ & $\begin{array}{c}1.596 \\
(0.866)^{*}\end{array}$ \\
\hline Terms of trade volatility & $\begin{array}{l}-0.0314 \\
(0.0308)\end{array}$ & $\begin{array}{c}-0.0382 \\
(0.0415)\end{array}$ \\
\hline Exchange rate volatility & $\begin{array}{c}0.00 \\
(0.00)\end{array}$ & $\begin{array}{c}0.00 \\
(0.00)\end{array}$ \\
\hline Inflation volatility & $\begin{array}{c}0.0270 \\
(0.0125)^{* *}\end{array}$ & $\begin{array}{c}0.0271 \\
(0.0149)^{*}\end{array}$ \\
\hline Banking crisis & $\begin{array}{l}-3.076 \\
(4.902)\end{array}$ & $\begin{array}{c}1.788 \\
(6.047)\end{array}$ \\
\hline $\begin{array}{l}\text { Wald } \chi^{2} \\
\text { Hansen } J \\
\text { AR(2) } z \\
\text { N }\end{array}$ & $\begin{array}{c}902.5^{* * *} \\
44.12 \\
0.57 \\
302\end{array}$ & $\begin{array}{c}1128.62^{* * *} \\
40.59 \\
0.22 \\
302\end{array}$ \\
\hline \multicolumn{3}{|c|}{$\begin{array}{l}\text { Notes: Heteroskedasticity and autocorrelation- } \\
\text { robust (asymptotic) } \bar{W} \text { indmeijer }(2005) \text {-corrected } \\
\text { standard errors reported in parentheses. * indi- } \\
\text { cates significance at } 10 \text { percent level, }{ }^{* *} \text { indicates } \\
\text { significance at the } 5 \text { percent level, and } * * * \text { indi- } \\
\text { cates significance at the } 1 \text { percent level. Period } \\
\text { dummies and a constant were included, but not } \\
\text { reported. }\end{array}$} \\
\hline
\end{tabular}




\section{Using alternative measures of growth volatility}

We estimate the benchmark model using 2 alternative definitions of our dependent variable. The 2 alternative measures of growth volatility are $\sum_{t}\left(g_{t}-\bar{g}\right)^{2}$ and $\sum_{t}\left|g_{t}-\bar{g}\right|$.

In Table $\bar{B} \overline{1}$, the first two columns report the results of the GMM estimates of the benchmark model where, as dependent variable, the standard deviation of real GDP per capita growth has been substituted by $\sum_{t}\left(g_{t}-\bar{g}\right)^{2}$. The last two columns of Table GMM estimates of the benchmark model where, as dependent variable, the standard deviation of real GDP per capita growth has been substituted by $\sum_{t}\left|g_{t}-\bar{g}\right|$. Odd-numbered columns refer to regressions using the product Herfindahl indicator, while even-numbered columns denote those using the 5-product indicator. We find that the results of the paper hold despite using alternative definitions of the dependent variable.

Table B.7: System GMM regressions for growth volatility, openness, and concentration with alternative definitions of the dependent variable $^{\dagger}$

\begin{tabular}{|c|c|c|c|c|}
\hline & $(D V 1)$ & $(D V 2)$ & $(D V 3)$ & $(D V 4)$ \\
\hline \multirow[t]{2}{*}{ Lagged volatility } & 0.129 & 0.0373 & 0.142 & 0.0543 \\
\hline & $(0.0973)$ & $(0.133)$ & $(0.120)$ & $(0.147)$ \\
\hline \multirow[t]{2}{*}{ Product concentration } & -11.92 & -6.539 & -10.07 & -8.103 \\
\hline & $(3.657)^{* * *}$ & $(3.555)^{*}$ & $(4.131)^{* *}$ & $(3.415)^{* *}$ \\
\hline \multirow[t]{2}{*}{ Openness x concentration } & 14.27 & 7.975 & 12.20 & 9.865 \\
\hline & $(4.208)^{* * *}$ & $(4.117)^{*}$ & $(4.922)^{* *}$ & $(3.970)^{* *}$ \\
\hline \multirow[t]{2}{*}{ Trade openness } & -2.548 & -4.021 & -1.660 & -4.441 \\
\hline & $(1.267)^{* *}$ & $(2.076)^{*}$ & $(1.195)$ & $(2.115)^{* *}$ \\
\hline \multirow{2}{*}{ Financial openness } & -0.0953 & -0.103 & -0.114 & -0.142 \\
\hline & $(0.0716)$ & $(0.0705)$ & $(0.0679)^{*}$ & $(0.0699)^{* *}$ \\
\hline \multirow[t]{2}{*}{ Capital flows volatility } & 0.152 & 0.127 & 0.0962 & 0.0711 \\
\hline & $(0.132)$ & $(0.159)$ & $(0.144)$ & $(0.159)$ \\
\hline \multirow[t]{2}{*}{ Foreign growth volatility } & 1.046 & 0.392 & 0.696 & 0.502 \\
\hline & $(0.456)^{* *}$ & $(0.399)$ & $(0.347)^{* *}$ & $(0.377)$ \\
\hline \multirow[t]{2}{*}{ Terms of trade volatility } & -0.00359 & -0.000783 & -0.00405 & -0.000646 \\
\hline & $(0.0156)$ & $(0.0162)$ & $(0.0154)$ & $(0.0196)$ \\
\hline \multirow[t]{2}{*}{ Exchange rate volatility } & 0.00 & 0.00 & -0.000 & -0.000 \\
\hline & $(0.00)$ & $(0.00)$ & $(0.000)$ & $(0.000)$ \\
\hline \multirow[t]{2}{*}{ Inflation volatility } & 0.00839 & 0.00855 & 0.0104 & 0.0101 \\
\hline & $(0.00460)^{*}$ & $(0.00547)$ & $(0.00479)^{* *}$ & $(0.00557)^{*}$ \\
\hline \multirow[t]{2}{*}{ Banking crisis } & -1.456 & -0.0141 & -0.819 & 0.246 \\
\hline & $(2.651)$ & $(2.478)$ & $(2.382)$ & $(2.303)$ \\
\hline Wald $\chi^{2}$ & $46.43^{* * *}$ & $28.45^{* *}$ & $712.9^{* * *}$ & $602.7^{* * *}$ \\
\hline Hansen J & 28.32 & 31.23 & 37.71 & 34.18 \\
\hline $\operatorname{AR}(2) z$ & 0.41 & -0.16 & 0.547 & 0.184 \\
\hline $\mathrm{N}$ & 302 & 302 & 302 & 302 \\
\hline \multicolumn{5}{|c|}{$\begin{array}{l}{ }^{\dagger} \text { Notes: Heteroskedasticity and autocorrelation-robust (asymptotic) } \\
(20 \overline{0}) \text { - corrected standard errors reported in parentheses. }{ }^{*} \text { indicates significance at } \\
10 \text { percent level, }{ }^{* *} \text { indicates significance at the } 5 \text { percent level, and }{ }^{* * *} \text { indicates sig- } \\
\text { nificance at the } 1 \text { percent level. Period dummies and a constant were included, but } \\
\text { not reported. }\end{array}$} \\
\hline
\end{tabular}




\section{Controlling for the effect of openness on export concentration}

We asses the total impact of openness and diversification on volatility taking into account the possible effect of openness on diversification by estimating a treatment effects model as in

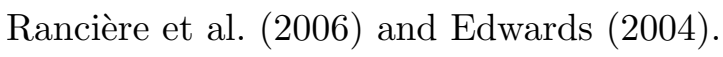

The treatment effects model allows to jointly estimate an outcome equation of growth volatility on controls - including an interaction term between openness and a dummy distinguishing diversified and non-diversified economies - and a Probit equation that controls for the (observable) determinants of diversification. The estimated treatment effects model is described by the equations below:

$$
\begin{gathered}
G D P V O L_{i, t}=\alpha+\beta_{1} O P E N_{i, t}+\beta_{2} C O N_{i, t}+\beta_{3} O P E N_{i, t} \times C O N_{i, t} \\
+\gamma \mathbf{X}_{i, t}+\epsilon_{i, t}, \\
C O N_{i t}=\left\{\begin{array}{ll}
=1 & \text { if } C O N_{i t}^{*}>0 \\
=0 & \text { otherwise }
\end{array}\right\} \\
C O N_{i, t}^{*}=\mu+\delta \mathbf{Z}_{i t}+\nu_{i t},
\end{gathered}
$$

where $i$ defines the country and $t$ the time period.

Equation (A. standard deviation of real GDP per capita growth. Trade openness, $O P E N_{i, t}$, the export product concentration dummy, $C O N_{i, t}$, and the interaction between these two previous variables, $O P E N_{i, t} \times C O N_{i, t}$, are the main regressors of interest. $\mathbf{X}_{i, t}$ is a $(1 \times m)$ vector that contains the same control variables included in the benchmark model. The export product concentration dummy takes value equal to 1 when the considered concentration index takes values above the threshold determined in the paperi

It is assumed that a country is not sufficiently diversified if the latent variable $C O N_{i t}^{*}$ is larger than 0. $C O N_{i t}^{*}$ is the dependent variable of the Probit equation (A of the following covariates: trade openness, income per capita in the first period, private credit as a share of GDP, fuel export over merchandise export, manufacturing export over merchandise export and population. The regressors of the Probit equation are lagged one period to avoid endogeneity. $\nu_{i t}$ is the disturbance term.

$\epsilon_{i, t}$ and $\nu_{i t}$ are assumed to be jointly normally distributed with a zero mean and the following variance-covariance matrix $\Sigma$ :

\footnotetext{
${ }^{11}$ The thresholds computed in the paper are: 0.154 for the product Herfindahl index, 0.481 for the 5 product index and 0.575 for the 10 product index.
} 


$$
\Sigma=\left[\begin{array}{cc}
\sigma_{\varepsilon}^{2} & \sigma_{\varepsilon \nu} \\
\sigma_{\nu \varepsilon} & 1
\end{array}\right]
$$

If the two equations are not independent, an OLS estimate of (AA timates. To overcome this problem, we estimate the model jointly using maximum likelihoodi $\overline{1} \overline{2} !$

The model is estimated using annual data on the same sample of countries and the same time period used in the paper ${ }^{1} \overline{3} ! \cdot$ Volatilities are computed as rolling standard deviations over 5 -year intervals.

Table 'B- $\mathrm{B} . \overline{8}$ '. shows the results of the treatment effects model. The results of the outcome equation, reported in the upper part of Table $\overline{\mathrm{B}} \cdot \overline{\mathrm{B}}$, show that even taking into account the effect of trade openness on diversification the results of the paper mostly hold. The coefficient on the openness variable continues to be negative while the coefficients on the interaction terms are positive. The interaction terms are significant in two out of three regressions. Only in the case of the 10 product indicator can we not fully confirm the results of the benchmarke model (not reported).

The results of the treatment equation, reported in the lower part of Table open manufactures exporters with a higher access to credit for the private sector indeed exhibit less concentrated exports as suggested by the reviewer. Higher fuel exports over merchandise exports and a smaller population are associated with more concentrated exports.

\footnotetext{
${ }^{12}$ The two-step approach produces similar results.

${ }^{13}$ The data for income per capita in the first period, private credit share of GDP, fuel export over merchandise export, manufacturing export over merchandise export and population, which are the covariates used in the Probit equation, are from the World Development Indicators database
} 
Table B.8: Treatment effects model: growth volatility, openness and product concentration ${ }^{\dagger}$

\begin{tabular}{|c|c|c|}
\hline & $(\operatorname{Tr} 1)$ & $(\operatorname{Tr} 2)$ \\
\hline \multicolumn{3}{|l|}{ Growth volatility } \\
\hline Trade openness & $\begin{array}{l}-0.049 \\
(0.637)\end{array}$ & $\begin{array}{l}-0.566 \\
(0.773)\end{array}$ \\
\hline Openness $\times$ concentration & $\begin{array}{c}3.583 \\
(1.196)^{* * *}\end{array}$ & $\begin{array}{c}2.649 \\
(1.084)^{* *}\end{array}$ \\
\hline Financial openness & $\begin{array}{c}-0.137 \\
(0.0681)^{* *}\end{array}$ & $\begin{array}{c}-0.138 \\
(0.078)^{*}\end{array}$ \\
\hline Terms of trade volatility & $\begin{array}{c}0.055 \\
(0.030)^{*}\end{array}$ & $\begin{array}{c}0.038 \\
(0.032)\end{array}$ \\
\hline Exchange rate volatility & $\begin{array}{c}0.012 \\
(0.016)\end{array}$ & $\begin{array}{c}0.008 \\
(0.017)\end{array}$ \\
\hline Capital flows volatility & $\begin{array}{c}0.596 \\
(0.173)^{* * *}\end{array}$ & $\begin{array}{c}0.557 \\
(0.160)^{* * *}\end{array}$ \\
\hline Foreign growth volatility & $\begin{array}{c}1.065 \\
(0.375)^{* * *}\end{array}$ & $\begin{array}{c}1.091 \\
(0.387)^{* * *}\end{array}$ \\
\hline Inflation volatility & $\begin{array}{c}0.009 \\
(0.010)\end{array}$ & $\begin{array}{c}0.011 \\
(0.012)\end{array}$ \\
\hline Banking crisis & $\begin{array}{c}1.055 \\
(0.317)^{* * *}\end{array}$ & $\begin{array}{c}1.051 \\
(0.325)^{* * *}\end{array}$ \\
\hline Product concentration & $\begin{array}{c}-2.192 \\
(0.798)^{* * *}\end{array}$ & $\begin{array}{c}-1.277 \\
(0.716)^{*}\end{array}$ \\
\hline \multicolumn{3}{|l|}{ Product concentration } \\
\hline Lagged trade openness & $\begin{array}{c}2.318 \\
(0.596)^{* * *}\end{array}$ & $\begin{array}{c}2.544 \\
(0.713)^{* * *}\end{array}$ \\
\hline Lagged income per capita in the first period & $\begin{array}{l}-0.000 \\
(0.000)\end{array}$ & $\begin{array}{c}-0.000 \\
(0.000)^{* *}\end{array}$ \\
\hline Lagged private credit share of GDP & $\begin{array}{c}-1.582 \\
(0.628)^{* *}\end{array}$ & $\begin{array}{c}-1.341 \\
(0.485)^{* * *}\end{array}$ \\
\hline Lagged fuel to merchandise exports & $\begin{array}{c}2.099 \\
(0.508)^{* * *}\end{array}$ & $\begin{array}{c}3.605 \\
(1.123)^{\text {*** }}\end{array}$ \\
\hline Lagged manufacturing to merchandise exports & $\begin{array}{c}-2.641 \\
(1.051)^{* *}\end{array}$ & $\begin{array}{c}-3.282 \\
(0.851)^{* * *}\end{array}$ \\
\hline Lagged population & $\begin{array}{l}-0.005 \\
(0.004)\end{array}$ & $\begin{array}{l}-0.006 \\
(0.004)\end{array}$ \\
\hline $\ln \left(\sigma_{\epsilon}\right)$ & $\begin{array}{c}(0.137) \\
0.368 \\
(0.067)^{* * *}\end{array}$ & $\begin{array}{c}(0.145) \\
0.377 \\
(0.071)^{* * *}\end{array}$ \\
\hline $\mathrm{N}$ & 1027 & 1027 \\
\hline
\end{tabular}

${ }^{\dagger}$ Notes: Huber-White (robust) standard errors reported in parentheses. ${ }^{*}$ indicates significance at 10 percent level, ${ }^{* *}$ indicates significance at the 5 percent level, and ${ }^{* * *}$ indicates significance at the 1 percent level. Period dummies and constants were included, but not reported. 


\section{Product concentration measures at different levels of sectoral aggregation}

We estimate the benchmark model substituting the product concentration measure with the corresponding measures computed at different levels of sectoral aggregation. This exercise provides results which are qualitatively similar to those obtained in the paper.

As an example, in Table model using the product Herfindahl index. We use the 3-digit Herfindahl index in G2a, the 2-digit Herfindahl index in G2b and finally the 1-digit Herfindahl index in G2c. Our results are qualitatively robust to using concentration indices at varying levels of aggregation.

Table B.9: System GMM regressions for growth volatility, openness, and product concentration, using as concentration indicator the product Herfindahl index computed at different levels of sectoral aggregation ${ }^{\dagger}$

\begin{tabular}{lccc}
\hline \hline & $(G 2 a)$ & $(G 2 b)$ & $(G 2 c)$ \\
\hline Lagged volatility & -0.001 & -0.000 & 0.032 \\
& $(0.14)$ & $(0.14)$ & $(0.16)$ \\
Product concentration & -27.173 & -17.800 & -23.976 \\
& $(9.95)^{* * *}$ & $(9.62)^{*}$ & $(11.05)^{* *}$ \\
Trade openness & -3.347 & -1.025 & -8.164 \\
& $(3.30)$ & $(3.67)$ & $(5.80)$ \\
Openness $\times$ concentration & 32.327 & 21.221 & 29.106 \\
& $(11.34)^{* * *}$ & $(11.27)^{*}$ & $(13.71)^{* *}$ \\
Financial openness & -0.398 & -0.362 & -0.331 \\
& $(0.18)^{* *}$ & $(0.17)^{* *}$ & $(0.16)^{* *}$ \\
Terms of trade volatility & 0.036 & 0.038 & 0.008 \\
& $(0.05)$ & $(0.05)$ & $(0.06)$ \\
Exchange rate volatility & -0.000 & -0.000 & -0.000 \\
Capital flows volatility & $(0.00)$ & $(0.00)$ & $(0.00)$ \\
Foreign growth volatility & 0.195 & 0.228 & 0.380 \\
& $(0.37)$ & $(0.36)$ & $(0.38)$ \\
Inflation volatility & 1.719 & 1.111 & -0.050 \\
& $(0.98)^{*}$ & $(0.98)$ & $(0.94)$ \\
Banking crisis & 0.032 & 0.028 & 0.015 \\
& $(0.02)^{* *}$ & $(0.02)^{*}$ & $(0.02)$ \\
& -3.080 & -0.163 & 6.331 \\
Wald $\chi^{2}$ & $(6.29)$ & $(6.34)$ & $(6.08)$ \\
Hansen $J$ & $5.28)$ \\
AR $(2) z$ & $596.4^{* * *}$ & $654.5^{* * *}$ & $645.2^{* * *}$ \\
$\mathrm{~N}$ & 34.23 & 31.60 & 37.39 \\
\hline \hline
\end{tabular}

${ }^{\dagger}$ Notes: Heteroskedasticity and autocorrelation-robust (asymptotic) "W'Windmeijer $(20 \overline{0} \bar{y}$ )-corrected standard errors reported in parentheses. ${ }^{*}$ indicates significance at 10 percent level, ${ }^{* *}$ indicates significance at the 5 percent level, and ${ }^{* * *}$ indicates significance at the 1 percent level. Period dummies and a constant were included, but not reported. 


\section{Product-Destination Herfindahl Index}

We estimate the benchmark model using as measure of concentration a product-destination Herfindahl index that measures concentration across destination-product pairs (based on the United Nations COMTRADE SITC Revision 2, 1 digit). As shown in Table B. our main results are confirmed by both GMM and random effects estimates.

Table B.10: System GMM and random effects regressions for growth volatility, openness, and product concentration, using as concentration indicator the product destination Herfindahl index ${ }^{\dagger \dagger}$

\begin{tabular}{|c|c|c|}
\hline & (GMM-ProdDest) & (RE-ProdDest) \\
\hline Lagged volatility & $\begin{array}{c}0.0833 \\
(0.134)\end{array}$ & \\
\hline Product destination concentration & $\begin{array}{c}-47.28 \\
(17.75)^{* * *}\end{array}$ & $\begin{array}{c}-24.87 \\
(11.82)^{* *}\end{array}$ \\
\hline Trade openness & $\begin{array}{l}-5.603 \\
(3.533)\end{array}$ & $\begin{array}{l}0.0807 \\
(1.400)\end{array}$ \\
\hline Openness $\times$ concentration & $\begin{array}{c}56.56 \\
(20.40)^{* * *}\end{array}$ & $\begin{array}{c}28.36 \\
(14.11)^{* *}\end{array}$ \\
\hline Financial openness & $\begin{array}{c}-0.286 \\
(0.170)^{*}\end{array}$ & $\begin{array}{c}-0.197 \\
(0.0780)^{* *}\end{array}$ \\
\hline Terms of trade volatility & $\begin{array}{c}-0.00665 \\
(0.0534)\end{array}$ & $\begin{array}{c}0.0587 \\
(0.0235)^{* *}\end{array}$ \\
\hline Exchange rate volatility & $\begin{array}{c}0.000 \\
(0.000)\end{array}$ & $\begin{array}{c}0.000 \\
(0.000)\end{array}$ \\
\hline Capital flows volatility & $\begin{array}{c}0.365 \\
(0.316)\end{array}$ & $\begin{array}{c}0.804 \\
(0.199)^{* * *}\end{array}$ \\
\hline Foreign growth volatility & $\begin{array}{c}1.886 \\
(1.108)^{*}\end{array}$ & $\begin{array}{c}0.898 \\
(0.364)^{* *}\end{array}$ \\
\hline Inflation volatility & $\begin{array}{c}0.0162 \\
(0.0137)\end{array}$ & $\begin{array}{c}0.00588 \\
(0.00729)\end{array}$ \\
\hline Banking crisis & $\begin{array}{l}-0.782 \\
(5.889)\end{array}$ & $\begin{array}{c}5.183 \\
(2.249)^{* *}\end{array}$ \\
\hline $\begin{array}{l}\text { Wald } \chi^{2} \\
\text { Hansen J } \\
\operatorname{AR}(2) \mathrm{z}\end{array}$ & $\begin{array}{c}689.9^{* * *} \\
27.30 \\
0.776\end{array}$ & \\
\hline $\begin{array}{l}\mathrm{R}^{2} \\
\mathrm{~F}\end{array}$ & 288 & $\begin{array}{c}0.259 \\
3276.6^{* * *} \\
350\end{array}$ \\
\hline \multicolumn{3}{|c|}{$\begin{array}{l}{ }^{\dagger} \text { Notes: In the GMM regression, heteroskedasticity and autocorrelation-robust } \\
\text { (asymptotic) } \\
\text { parentheses. }{ }^{*} \text { indicates significance at } 10 \text { percent level, }{ }^{* *} \text { indicates signifi- } \\
\text { cance at the } 5 \text { percent level, and }{ }^{* * *} \text { indicates significance at the } 1 \text { percent } \\
\text { level. Period dummies and a constant were included, but not reported. } \\
{ }^{\dagger} \text { Notes: In the RE regression, Huber-White (robust) standard errors are reported } \\
\text { in parentheses. }{ }^{*} \text { indicates significance at } 10 \text { percent level, }{ }^{* *} \text { indicates signifi- } \\
\text { cance at the } 5 \text { percent level, and }{ }^{* * *} \text { indicates significance at the } 1 \text { percent level. } \\
\text { Period dummies and a constant were included, but not reported. }\end{array}$} \\
\hline
\end{tabular}




\section{0-year averages}

Table main results of the paper hold.

Table B.11: System GMM regressions for growth volatility, openness, and product concentration using 10-year averages $^{\dagger}$

\begin{tabular}{|c|c|c|}
\hline & (10years- 1$)$ & (10yers-2) \\
\hline Lagged growth volatility & $\begin{array}{c}0.231 \\
(0.10)^{* *}\end{array}$ & $\begin{array}{c}0.197 \\
(0.09)^{* *}\end{array}$ \\
\hline Product concentration & $\begin{array}{l}-20.199 \\
(9.52)^{* *}\end{array}$ & $\begin{array}{l}-10.343 \\
(2.99)^{* * *}\end{array}$ \\
\hline Openness x concentration & $\begin{array}{c}26.655 \\
(12.70)^{* *}\end{array}$ & $\begin{array}{c}12.253 \\
(4.71)^{* * *}\end{array}$ \\
\hline Trade openness & $\begin{array}{c}-0.941 \\
(1.79)\end{array}$ & $\begin{array}{l}-4.406 \\
(2.57)^{*}\end{array}$ \\
\hline Financial openness & $\begin{array}{c}-0.391 \\
(0.20)^{* *}\end{array}$ & $\begin{array}{l}-0.252 \\
(0.19)\end{array}$ \\
\hline Terms of trade volatility & $\begin{array}{c}0.094 \\
(0.10)\end{array}$ & $\begin{array}{c}0.182 \\
(0.06)^{* * *}\end{array}$ \\
\hline Exchange rate volatility & $\begin{array}{l}0.020 \\
(0.01)\end{array}$ & $\begin{array}{c}0.018 \\
(0.01)\end{array}$ \\
\hline Capital flows volatility & $\begin{array}{l}-0.457 \\
(0.30)\end{array}$ & $\begin{array}{l}-0.406 \\
(0.26)\end{array}$ \\
\hline Foreign growth volatility & $\begin{array}{c}1.571 \\
(0.68)^{* *}\end{array}$ & $\begin{array}{l}0.876 \\
(0.57)\end{array}$ \\
\hline Inflation volatility & $\begin{array}{c}0.020 \\
(0.01)^{* *}\end{array}$ & $\begin{array}{l}0.013 \\
(0.01)\end{array}$ \\
\hline Banking crisis & $\begin{array}{c}-2.449 \\
(2.01)\end{array}$ & $\begin{array}{l}1.571 \\
(1.61)\end{array}$ \\
\hline Wald $\chi^{2}$ & $77.3^{* * *}$ & $50.6^{* * *}$ \\
\hline Hansen J & 19.208 & 19.324 \\
\hline $\operatorname{AR}(2) z$ & 0.444 & 0.436 \\
\hline $\mathrm{N}$ & 126 & 126 \\
\hline \multicolumn{3}{|c|}{ 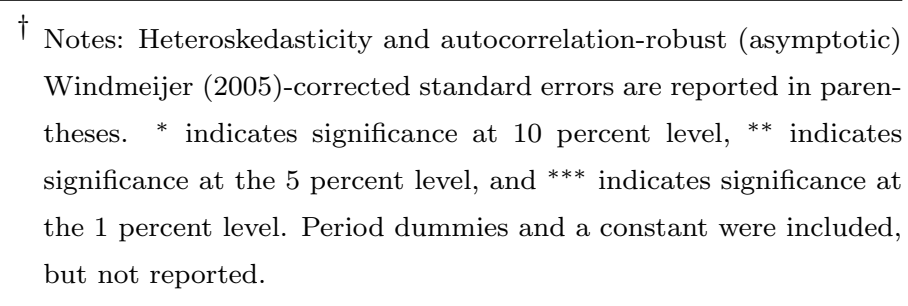 } \\
\hline
\end{tabular}

\footnotetext{
${ }^{14}$ Standard deviations are computed over 10 year periods while the remaining explanatory variables are computed as 10 year averages of the underlying annual data. Therefore, now we now have $T=3$ and $N=77$.
} 